Article

\title{
Steroidal Glycosides from Allium tuberosum Seeds and Their Roles in Promoting Testosterone Production of Rat Leydig Cells
}

\author{
Da-Bing Zhang ${ }^{1,2}$ and Xian-Yong Wei ${ }^{1,3, *}$ \\ 1 Key Laboratory of Coal Processing and Efficient Utilization, Ministry of Education, China University of \\ Mining \& Technology, Xuzhou 221116, Jiangsu, China; dbzhang@sina.cn \\ 2 Jiangsu Hanbon Science \& Technology Co., Ltd., Huaian 223005, Jiangsu, China \\ 3 State Key Laboratory of High-efficiency Coal Utilization and Green Chemical Engineering, \\ Ningxia University, Yinchuan 750021, Ningxia, China \\ * Correspondence: wei_xianyong@163.com
}

Received: 22 October 2020; Accepted: 14 November 2020; Published: 22 November 2020

\begin{abstract}
A systematic phytochemical study on the components in the seeds of Allium tuberosum was performed, leading to the isolation of 27 steroidal glycosides (SGs 1-27). The structures of SGs were identified mainly by nuclear magnetic resonance and mass spectrometries as well as the necessary chemical evidence. In the SGs, 1-10 and 22-26 are new steroidal saponin analogues. An in vitro bioassay indicates that $1,2,7, \mathbf{8}, \mathbf{1 0}, \mathbf{1 3}-\mathbf{1 5}, \mathbf{2 0}, \mathbf{2 3}$, and 26 display promotional roles in testosterone production of rat Leydig cells with the $\mathrm{EC}_{50}$ values of 1.0 to $4.5 \mu \mathrm{M}$, respectively.
\end{abstract}

Keywords: liliaceae; Allium tuberosum; steroidal saponin; allituberoside

\section{Introduction}

Steroidal saponins (SSs) are the important class of secondary metabolites in many medicinal plants. Structurally, SSs are mostly in the form of glycosides which are composed of one or more hydrophilic sugar residues and hydrophobic steroidal part [1]. All the time, they have been a kind of constituents concerned by scholars owing to the wide range of their biological actions. For example, SSs from Dioscorea zingiberensis are widely used for preventing cardiovascular diseases [2], SSs of Ophiopogon japonicus displayed multiple biofunctions of anticancer, immunomodulation, anti-oxidation, anti-inflammation, and anti-diabetes [3]; SSs in Paris species are used to treat cancer and bleeding [4], and timosaponin AIII obtained from Anemarrhena asphodeloides exhibits inhibitory activity against tumor cells [5].

SSs have been reported in more than 40 different Allium species [6]. Allium tuberosum is a type of Allium plant widely cultivated as food in China, and the mature seeds of this plant are used as a traditional herb medicine treating both impotence and nocturnal emissions [7]. The seeds of this plant are famous for their sulfur-containing biologically active natural products [8-10], and they also contain amounts of SSs as the main constituents [11-17]. Previous studies reported many SSs from A. tuberosum seeds (ATSs), while a systematic phytochemical investigation for clarifying the bioactive SSs is still necessary. Recently, a systematic phytochemical study on the components in ATSs finally let us to obtain total 27 SSs (1-27) (Figure 1). According to the traditional pharmacological action of ATSs, all isolated compounds were tested for their effects on testosterone production of rat Leydig cells. 

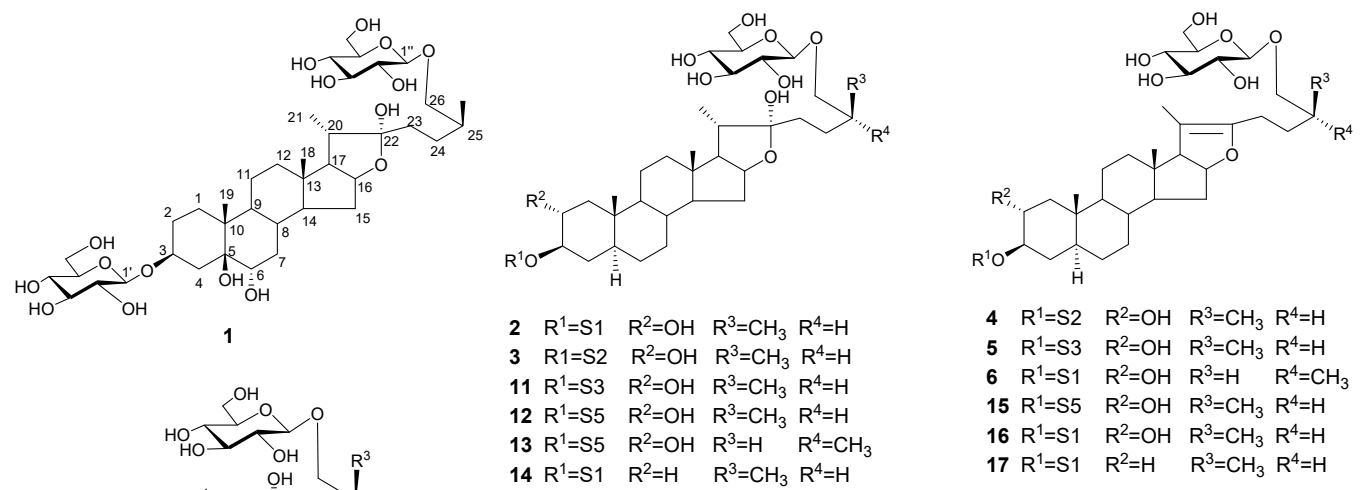

$4 \quad \mathrm{R}^{1}=\mathrm{S} 2 \quad \mathrm{R}^{2}=\mathrm{OH} \quad \mathrm{R}^{3}=\mathrm{CH}_{3} \quad \mathrm{R}^{4}=\mathrm{H}$

$5 \quad \mathrm{R}^{1}=\mathrm{S} 3 \quad \mathrm{R}^{2}=\mathrm{OH} \quad \mathrm{R}^{3}=\mathrm{CH}_{3} \quad \mathrm{R}^{4}=\mathrm{H}$

$6 \quad \mathrm{R}^{1}=\mathrm{S} 1 \quad \mathrm{R}^{2}=\mathrm{OH} \quad \mathrm{R}^{3}=\mathrm{H} \quad \mathrm{R}^{4}=\mathrm{CH}_{3}$

$15 R^{1}=\mathrm{S} 5 \quad R^{2}=\mathrm{OH} \quad \mathrm{R}^{3}=\mathrm{CH}_{3} \quad \mathrm{R}^{4}=\mathrm{H}$

$16 R^{1}=\mathrm{S} 1 \quad R^{2}=\mathrm{OH} \quad \mathrm{R}^{3}=\mathrm{CH}_{3} \mathrm{R}^{4}=\mathrm{H}$

$17 \mathrm{R}^{1}=\mathrm{S} 1 \quad \mathrm{R}^{2}=\mathrm{H} \quad \mathrm{R}^{3}=\mathrm{CH}_{3} \quad \mathrm{R}^{4}=\mathrm{H}$

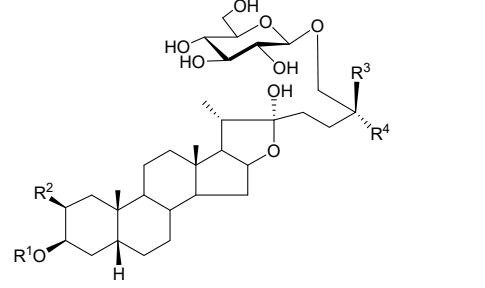

$7 \quad \mathrm{R}^{1}=\mathrm{S} 3 \quad \mathrm{R}^{2}=\mathrm{OH} \quad \mathrm{R}^{3}=\mathrm{CH}_{3} \quad \mathrm{R}^{4}=\mathrm{H}$

$8 \quad R^{1}=\mathrm{S} 3 \quad R^{2}=\mathrm{OH} \quad R^{3}=\mathrm{H} \quad \mathrm{R}^{4}=\mathrm{CH}_{3}$

$9 \mathrm{R}^{1}=\mathrm{S} 4 \quad \mathrm{R}^{2}=\mathrm{OH} \quad \mathrm{R}^{3}=\mathrm{CH}_{3} \mathrm{R}^{4}=\mathrm{H}$

$18 R^{1}=\mathrm{S} 6 \quad \mathrm{R}^{2}=\mathrm{H} \quad \mathrm{R}^{3}=\mathrm{CH}_{3} \quad \mathrm{R}^{4}=\mathrm{H}$

$19 \mathrm{R}^{1}=\mathrm{S} 6 \quad \mathrm{R}^{2}=\mathrm{H} \quad \mathrm{R}^{3}=\mathrm{H} \quad \mathrm{R}^{4}=\mathrm{CH}_{3}$
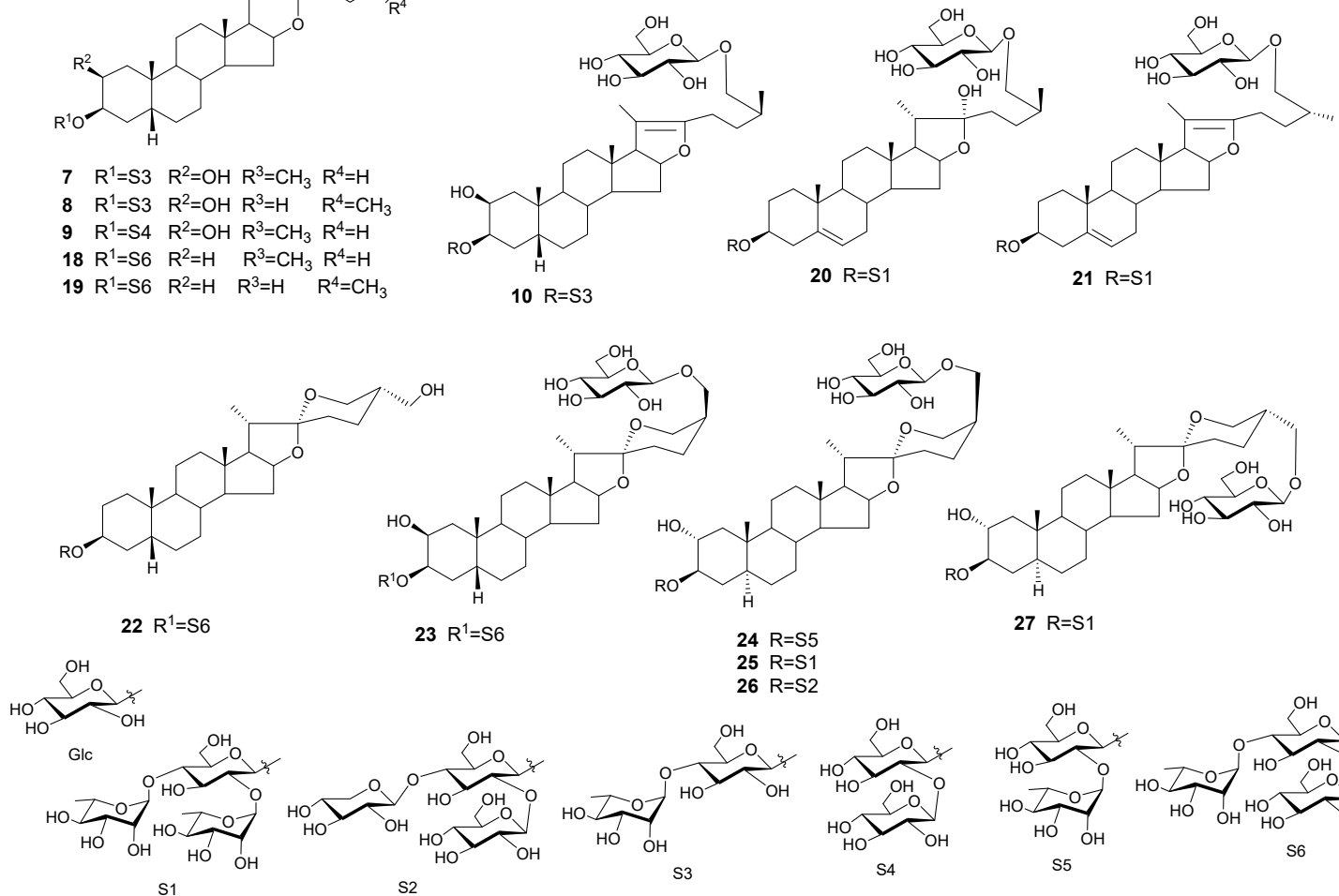

$27 \mathrm{R}=\mathrm{S} 1$

S2

Figure 1. Structures of 1-27.

\section{Results and Discussion}

By comparing the nuclear magnetic resonance (NMR) data with the reported values, the known compounds 11-18, 20, 21, and 27 are identified as trigofoenoside B (11) [18], trigoneoside Xa (12) [19], trigoneoside $\mathrm{Xb}$ (13) [19], nicotianoside F (14) [20], tuberoside A (15) [11], tuberoside B (16) [11], $26-O-\beta$-D-glucopyranosyl-(25S)- $5 \alpha$-furostan- ${ }^{20(22)}$-ene-3 $\beta, 26$-glycol-3-O- $\alpha$-L-rhamnopyranosyl-( $\left.1 \rightarrow 4\right)$ [ $\alpha$-L-rhamnopyranosyl $(1 \rightarrow 2)]-\beta$-D-glucopyranoside (17) [21], shatavarin I (18) [22], protoneodioscin (20) [23], pseudoprotodioscin (21) [24], tuberoside L (27) [13], respectively. The structure of 19 has been already registered in CAS with the numbers of 1493828-40-2 and also reported as 3-O- $\alpha$-Lrhamnopyranosyl $(1 \rightarrow 4)$-[ $\beta$-D-glucopyranosyl $(1 \rightarrow 2)]$ - $\beta$-D-glucopyranosyl-26-O- $\beta$-D-glucopyranosyl(25R)-5 $\beta$-furostane-3 $\beta, 22 \alpha, 26$-triol in the literature [25], but no full NMR data are available for them. By systematic spectroscopic data analysis, its NMR data are assigned (see Supplementary Materials). The remaining new analogues are identified mainly by analysis of NMR and MS spectra as well as the necessary chemical evidence such as acid hydrolysis experiments for determining absolute configuration of the sugar units in the structures.

Compound $\mathbf{1}$ is in the form of white amorphous powders with a molecular formula of $\mathrm{C}_{39} \mathrm{H}_{66} \mathrm{O}_{16}$ as determined by HR-ESI-MS at $m / z 789.4272[\mathrm{M}-\mathrm{H}]^{-}$(calcd for $\mathrm{C}_{39} \mathrm{H}_{65} \mathrm{O}_{16}, 789.4273$ ) together with its ${ }^{13} \mathrm{C}$ NMR data (Table 1). In the ${ }^{1} \mathrm{H}$ NMR spectrum, four typical methyl proton signals at $\delta 0.88(3 \mathrm{H}$, 
s), $1.17(3 \mathrm{H}, \mathrm{s}), 1.33(3 \mathrm{H}, \mathrm{d}, J=6.8 \mathrm{~Hz}), 1.05(3 \mathrm{H}, \mathrm{d}, J=7.0 \mathrm{~Hz})$, and two anomeric proton signals at $\delta 4.83(1 \mathrm{H}, \mathrm{d}, J=7.8 \mathrm{~Hz})$ and $5.11(1 \mathrm{H}, \mathrm{d}, J=7.8 \mathrm{~Hz})$ are observed. Its ${ }^{13} \mathrm{C}$ NMR spectrum exhibits total 39 carbon resonances including 27 ones due to the aglycone part and twelve ones attributed to the two hexoses. Comparison of NMR data suggests that 1 has the identical planar structure of aglycone skeleton with $26-O-\beta$-D-glucopyranosyl-(25S)-3 $\beta, 5 \beta, 6 \alpha, 22,26$-pentahydroxyl-5 $\beta$-furostane 3-O- $\alpha$-L-rhamnopyranosyl-( $1 \rightarrow 4)-\beta$-D-glucopyranoside [17], which is further confirmed by detailed analyses of ${ }^{1} \mathrm{H}^{1} \mathrm{H}$ COSY, HSQC, and HMBC spectra of $\mathbf{1}$. The chemical shifts of H-26a $(\delta 4.09)$ and $\mathrm{H}-26 \mathrm{~b}(\delta 3.50)(\Delta \mathrm{ab}>0.57)$ further confirm the C-25S configuration of 1 [26]. Starting from the anomeric protons at $\delta 4.83\left(\mathrm{H}-1^{\prime}\right)$ and $5.11\left(\mathrm{H}-1^{\prime \prime}\right)$, the proton signals of sugars are delineated relying on the ${ }^{1} \mathrm{H}^{-1} \mathrm{H}$ COSY correlations, contributing to establish the structures of the two sugar unites. The large coupling constants of $J_{1^{\prime}, 2^{\prime}}(7.8 \mathrm{~Hz})$ and the ${ }^{13} \mathrm{C}$ NMR data facilitate defining the sugars as $\beta$-D-glucopyranoses, which is also supported by the result of the acid hydrolysis experiment. The connectivity of the glucopyranose is identified by the HMBC correlations of $\delta 4.83\left(\mathrm{H}-1^{\prime}\right) / 79.2$ $(\mathrm{C}-3)$, and $\delta 5.11\left(\mathrm{H}-1^{\prime \prime}\right) / 75.4$ (C-26), respectively. Consequently, the structure of 1 is elucidated as 26 -O- $\beta$-D-glucopyranosyl-(25S)-furost-3 $\beta, 5 \beta, 6 \alpha, 22 \alpha, 26$-pentanol 3-O- $\beta$-D-glucopyranoside, named allituberoside A.

Table 1. ${ }^{13} \mathrm{C}$ NMR data for $\mathbf{1}-\mathbf{8}$ ( $\delta$ in pyridine- $\left.d_{5}\right)$.

\begin{tabular}{|c|c|c|c|c|c|c|c|c|}
\hline POS. & 1 & 2 & 3 & 4 & 5 & 6 & 7 & 8 \\
\hline 1 & 36.0 & 45.9 & 45.9 & 46.0 & 45.8 & 45.9 & 40.3 & 40.3 \\
\hline 2 & 29.2 & 70.6 & 70.6 & 70.5 & 70.4 & 70.6 & 66.9 & 66.9 \\
\hline 3 & 79.2 & 85.1 & 85.1 & 85.1 & 84.9 & 85.1 & 80.2 & 80.2 \\
\hline 4 & 35.2 & 33.5 & 33.5 & 33.5 & 33.9 & 33.5 & 31.7 & 31.7 \\
\hline 5 & 73.1 & 44.6 & 44.7 & 44.7 & 44.6 & 44.7 & 36.4 & 36.4 \\
\hline 6 & 66.2 & 28.2 & 28.2 & 28.2 & 28.1 & 28.2 & 26.2 & 26.2 \\
\hline 7 & 35.6 & 32.3 & 32.3 & 32.5 & 32.4 & 32.4 & 26.7 & 26.7 \\
\hline 8 & 34.6 & 34.6 & 34.6 & 34.4 & 34.4 & 34.4 & 35.5 & 35.5 \\
\hline 9 & 44.7 & 54.5 & 54.5 & 54.4 & 54.4 & 54.4 & 41.4 & 41.4 \\
\hline 10 & 43.1 & 36.9 & 36.9 & 36.9 & 36.9 & 36.9 & 36.9 & 36.9 \\
\hline 11 & 21.9 & 21.5 & 21.5 & 21.6 & 21.6 & 21.6 & 21.3 & 21.4 \\
\hline 12 & 40.1 & 40.1 & 40.2 & 39.8 & 39.8 & 39.8 & 40.5 & 40.5 \\
\hline 13 & 41.0 & 41.1 & 41.1 & 43.7 & 43.7 & 43.8 & 41.2 & 41.2 \\
\hline 14 & 56.3 & 56.3 & 56.3 & 54.7 & 54.6 & 54.6 & 56.3 & 56.3 \\
\hline 15 & 32.4 & 32.4 & 32.4 & 34.4 & 34.3 & 34.4 & 32.4 & 32.4 \\
\hline 16 & 81.1 & 81.1 & 81.2 & 84.5 & 84.5 & 84.5 & 81.2 & 81.2 \\
\hline 17 & 63.8 & 63.9 & 63.9 & 64.6 & 64.6 & 64.6 & 64.0 & 64.0 \\
\hline 18 & 16.7 & 16.7 & 16.7 & 14.4 & 14.4 & 14.4 & 16.7 & 16.7 \\
\hline 19 & 17.6 & 13.6 & 13.6 & 13.6 & 13.4 & 13.6 & 23.8 & 23.8 \\
\hline 20 & 40.7 & 40.7 & 40.7 & 103.6 & 103.6 & 103.6 & 40.7 & 40.7 \\
\hline 21 & 16.5 & 16.5 & 16.5 & 11.8 & 11.8 & 11.8 & 16.5 & 16.5 \\
\hline 22 & 110.7 & 110.6 & 110.6 & 152.4 & 152.4 & 152.4 & 110.6 & 110.6 \\
\hline 23 & 37.2 & 37.2 & 37.2 & 31.4 & 31.4 & 31.5 & 37.2 & 37.3 \\
\hline 24 & 28.4 & 28.3 & 28.4 & 23.7 & 23.6 & 23.7 & 28.4 & 28.4 \\
\hline 25 & 34.5 & 34.5 & 34.5 & 33.8 & 33.7 & 33.4 & 34.5 & 34.3 \\
\hline 26 & 75.4 & 75.4 & 75.4 & 75.3 & 75.2 & 75.0 & 75.4 & 75.3 \\
\hline \multirow[t]{2}{*}{27} & 17.5 & 17.5 & 17.5 & 17.2 & 17.2 & 17.4 & 17.5 & 17.5 \\
\hline & 3-O-Glc & 3-O-Glc & 3-O-Glc & 3-O-Glc & 3-O-Glc & 3-O-Glc & 3-O-Glc & 3-O-Glc \\
\hline $1^{\prime}$ & 102.2 & 100.9 & 100.6 & 100.6 & 103.0 & 100.9 & 104.0 & 104.0 \\
\hline $2^{\prime}$ & 74.8 & 77.9 & 77.3 & 77.3 & 75.3 & 77.9 & 75.0 & 75.0 \\
\hline $3^{\prime}$ & 79.0 & 77.9 & 76.5 & 76.5 & 76.6 & 77.9 & 76.6 & 76.6 \\
\hline $4^{\prime}$ & 71.6 & 78.5 & 81.4 & 81.4 & 78.3 & 78.7 & 78.1 & 78.1 \\
\hline $5^{\prime}$ & 78.7 & 77.2 & 77.8 & 77.8 & 77.4 & 77.2 & 77.4 & 77.5 \\
\hline \multirow[t]{2}{*}{$6^{\prime}$} & 62.4 & 61.1 & 61.4 & 61.4 & 61.3 & 61.1 & 61.3 & 61.3 \\
\hline & 26-O-Glc & $2^{\prime}$-O-Rha & $2^{\prime}$-O-Rha & $2^{\prime}$-O-Rha & $4^{\prime}$-O-Rha & $2^{\prime}$-O-Rha & $4^{\prime}-\mathrm{O}-\mathrm{Rha}$ & $4^{\prime}-\mathrm{O}-\mathrm{Rh}$ \\
\hline $1^{\prime \prime}$ & 105.2 & 102.1 & 102.2 & 102.1 & 102.7 & 102.1 & 102.7 & 102.7 \\
\hline $2^{\prime \prime}$ & 75.3 & 72.5 & 72.4 & 72.4 & 72.6 & 72.5 & 72.6 & 72.7 \\
\hline $3^{\prime \prime}$ & 78.6 & 72.8 & 72.8 & 72.8 & 72.8 & 72.8 & 72.8 & 72.8 \\
\hline
\end{tabular}


Table 1. Cont

\begin{tabular}{|c|c|c|c|c|c|c|c|c|}
\hline POS. & 1 & 2 & 3 & 4 & 5 & 6 & 7 & 8 \\
\hline $4^{\prime \prime}$ & 71.7 & 74.1 & 74.1 & 74.1 & 74.0 & 74.1 & 74.0 & 74.0 \\
\hline $5^{\prime \prime}$ & 78.5 & 69.5 & 69.6 & 69.6 & 70.5 & 69.5 & 70.4 & 70.4 \\
\hline \multirow[t]{2}{*}{$6^{\prime \prime}$} & 62.8 & 18.6 & 18.6 & 18.6 & 18.6 & 18.6 & 18.6 & 18.6 \\
\hline & & $4^{\prime}$-O-Rha & $4^{\prime}-O-X y 1$ & $4^{\prime}-O-X y l$ & 26-O-Glc & $4^{\prime}-\mathrm{O}-\mathrm{Rh} a$ & 26-O-Glc & 26-O-Glc \\
\hline $1^{\prime \prime \prime}$ & & 102.9 & 105.8 & 105.8 & 105.2 & 103.0 & 105.2 & 105.0 \\
\hline $2^{\prime \prime \prime}$ & & 72.6 & 75.0 & 75.0 & 75.2 & 72.6 & 75.2 & 75.2 \\
\hline $3^{\prime \prime \prime}$ & & 72.8 & 78.4 & 78.4 & 78.6 & 72.8 & 78.6 & 78.6 \\
\hline $4^{\prime \prime \prime}$ & & 73.9 & 70.8 & 70.8 & 71.7 & 73.9 & 71.7 & 71.7 \\
\hline $5^{\prime \prime \prime}$ & & 70.5 & 67.4 & 67.4 & 78.6 & 70.5 & 78.5 & 78.5 \\
\hline \multirow[t]{2}{*}{$6^{\prime \prime \prime}$} & & 18.5 & & & 62.8 & 18.6 & 62.8 & 62.8 \\
\hline & & 26-O-Glc & 26-O-Glc & 26-O-Glc & & 26-O-Glc & & \\
\hline $1^{\prime \prime \prime \prime}$ & & 105.2 & 105.2 & 105.2 & & 104.9 & & \\
\hline $2^{\prime \prime \prime \prime}$ & & 75.3 & 75.3 & 75.3 & & 75.2 & & \\
\hline $3^{\prime \prime \prime \prime \prime}$ & & 78.6 & 78.7 & 78.7 & & 78.7 & & \\
\hline $4^{\prime \prime \prime \prime}$ & & 71.7 & 71.7 & 71.7 & & 71.7 & & \\
\hline $5^{\prime \prime \prime \prime}$ & & 78.6 & 78.5 & 78.6 & & 78.6 & & \\
\hline $6^{\prime \prime \prime \prime}$ & & 62.8 & 62.8 & 62.9 & & 62.9 & & \\
\hline
\end{tabular}

Compound 2 has a molecular formula of $\mathrm{C}_{51} \mathrm{H}_{86} \mathrm{O}_{23}$ as determined by HR-ESI-MS. Its ${ }^{1} \mathrm{H}$ NMR spectrum obviously shows four typical methyl proton signals at $\delta 0.87(3 \mathrm{H}, \mathrm{s}), 0.90(3 \mathrm{H}, \mathrm{s}), 1.05$ $(3 \mathrm{H}, \mathrm{d}, J=7.0 \mathrm{~Hz})$, and $1.31(3 \mathrm{H}, \mathrm{d}, J=6.8 \mathrm{~Hz})$, and four anomeric proton signals at $\delta 4.82(1 \mathrm{H}$, $\mathrm{d}, J=7.9 \mathrm{~Hz}), 5.03(1 \mathrm{H}, \mathrm{d}, J=7.1 \mathrm{~Hz}), 5.86(1 \mathrm{H}, \mathrm{br} \mathrm{s})$, and $6.40(1 \mathrm{H}, \mathrm{br} \mathrm{s})$. Its ${ }^{13} \mathrm{C}$ NMR spectrum exhibits total 45 carbon resonances including 27 ones due to the aglycone part and 24 ones attributed to the sugar moieties consisting of four hexoses. The ${ }^{13} \mathrm{C}$ NMR data of 2 suggests that it had the identical aglycone skeleton with 11 and the same sugar moieties with 14, which is supported by its ${ }^{1} \mathrm{H}^{-1} \mathrm{H}$ COSY, HSQC, and HMBC spectral data. The chemical shifts of $\mathrm{H}-26 \mathrm{a}(\delta 4.10)$ and $\mathrm{H}-26 \mathrm{~b}(\delta 3.49)(\Delta \mathrm{ab}>0.57)$ further confirm the C-25S configuration of 2 . Thus, the structure of 2 is elucidated as $26-O-\beta$-D-glucopyranosyl-(25S)- $5 \alpha$-furost-2 $\alpha, 3 \beta, 22 \alpha, 26$-tetrol 3-O- $\alpha$-L-rhamnopyranosyl

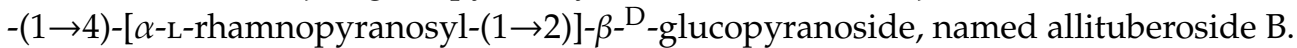

Compound 3 displays a molecular formula of $\mathrm{C}_{50} \mathrm{H}_{84} \mathrm{O}_{23}$ as confirmed by HR-ESI-MS. Its NMR data suggests that 3 has the identical structure with 2 except for the terminal sugar unit at C-4'. The neutral missing fragment of $136 \mathrm{Da}$ presented on the mass spectrum of 3 suggests that 3 has a xylose moiety, and detailed analyses of ${ }^{1} \mathrm{H}-{ }^{1} \mathrm{H}$ COSY, HSQC, and HMBC spectra finally identified the structure of the C-3 sugar chain of 3 to be 3-O- $\beta$-D-xylopyranosyl-( $(1 \rightarrow 4)$-[ $\alpha$-L-rhamnopyranosyl-( $1 \rightarrow 2)]-\beta$-D-glucopyranoside. The chemical shifts of $\mathrm{H}-26 \mathrm{a}(\delta 4.11)$ and $\mathrm{H}-26 \mathrm{~b}(\delta 3.49)(\Delta \mathrm{ab}>0.57)$ further confirm the $\mathrm{C}-25 S$ configuration of 3 . Therefore, the structure of 3 is elucidated as 26-O- $\beta$-D-glucopyranosyl-(25S)- $5 \alpha$-furost-2 $\alpha, 3 \beta, 22 \alpha, 26$-tetrol 3 -O- $\beta$-D-xylopyranosyl-( $1 \rightarrow 4)$-[ $\alpha$-L-rhamnopyranosyl-( $1 \rightarrow 2)]-\beta$-D-glucopyranoside, $\quad$ named allituberoside $\mathrm{C}$.

Compound 4 has a molecular formula of $\mathrm{C}_{50} \mathrm{H}_{82} \mathrm{O}_{22}$ as determined by HR-ESI-MS. Its NMR data suggests that the structure of 4 is closely similar to that of 3 except for the different substructure surrounding C-20 and C-22 positions. In its ${ }^{13} \mathrm{C}$ NMR spectrum, the characteristic carbon signals of $\delta 103.6$ and 152.4 which are the same as those of 15-17 indicate the existence of the $\Delta^{20(22)}$-ene substructure in 4, which is supported by the HMBC correlations of $\delta 1.62$ $(\mathrm{H}-21) / 103.6$ (C-20) and 152.4 (C-22). By detailed analysis of ${ }^{1} \mathrm{H}-{ }^{1} \mathrm{H}$ COSY, HSQC, and HMBC spectra, the structure of 4 is further confirmed, and its C-25S configuration is deduced according to the chemical shifts of H-26a $(\delta 4.10)$ and H-26b $(\delta 3.49)(\Delta \mathrm{ab}>0.57)$. Subsequently, the structure of 4 is elucidated as $26-O-\beta$-D-glucopyranosyl-(25S)- $5 \alpha$-furost- $\Delta^{20(22)}$-ene- $2 \alpha, 3 \beta, 26$-triol 3-O- $\beta$-D-xylopyranosyl-( $1 \rightarrow 4)$-[ $\alpha$-L-rhamnopyranosyl-( $(1 \rightarrow 2)]-\beta$-D-glucopyranoside, $\quad$ named allituberoside D. 
Compound 5 has a molecular formula of $\mathrm{C}_{45} \mathrm{H}_{74} \mathrm{O}_{18}$ as established by HR-ESI-MS. Its NMR data suggests that except for the $\mathrm{C}-3$ sugar chain, 5 and 4 have the same structure. Analyses of the ${ }^{1} \mathrm{H}-{ }^{1} \mathrm{H}$ COSY spectrum give the structures of the glucose and rhamnose comprising the C-3 sugar chain, and the HMBC correlations between $\delta 5.92\left(\mathrm{H}-1^{\prime \prime}\right.$ of Rha) and 78.3 (C-4' of 3-O-Glc) confirm their connectivity. By detailed analyses of ${ }^{1} \mathrm{H}-{ }^{1} \mathrm{H}$ COSY, HSQC, and HMBC spectra, the structure of $\mathbf{5}$ is further confirmed. The C-25S configuration is deduced according to the chemical shifts of H-26a $(\delta 4.10)$ and H-26b $(\delta 3.49)(\Delta \mathrm{ab}>0.57)$. Thus, the structure of 5 is elucidated as $26-O-\beta$-D-glucopyranosyl-(25S)- $5 \alpha$-furost- $\Delta^{20(22)}$-ene-2 $2 \alpha, 3 \beta, 26$-triol 3-O- $\alpha$-L-rhamnopyranosyl-( $1 \rightarrow 2)-\beta$-D-glucopyranoside, named allituberoside E.

Compound 6 has a molecular formula of $\mathrm{C}_{51} \mathrm{H}_{84} \mathrm{O}_{22}$ as identified by HR-ESI-MS. Its NMR data suggest that $\mathbf{6}$ has the identical aglycone structure with $\mathbf{5}$ and has the same C-3 sugar chain as 2 . According to its ${ }^{1} \mathrm{H}^{-}{ }^{1} \mathrm{H}$ COSY, HSQC and HMBC spectra, the structure of 6 is confirmed. The chemical shifts of H-26a $(\delta 3.96)$ and H-26b $(\delta 3.63)$ $(\Delta \mathrm{ab}<0.48)$ further deduce its $\mathrm{C}-25 R$ configuration [26]. Therefore, the structure of 6 is elucidated as 26-O- $\beta$-D-glucopyranosyl-(25R)- $5 \alpha$-furost- $\Delta^{20(22)}$-ene- $2 \alpha, 3 \beta, 26$-triol 3 -O- $\alpha$-L-rhamnopyranosyl-( $1 \rightarrow 4)$-[ $\alpha$-L-rhamnopyranosyl-( $1 \rightarrow 2)]-\beta$-D-glucopyranoside, $\quad$ named allituberoside $\mathrm{F}$.

Compound 7 with a molecular formula of $\mathrm{C}_{45} \mathrm{H}_{76} \mathrm{O}_{19}$ confirmed by HR-ESI-MS has the same sugar moieties as 5 by detailed comparison of the NMR data. Further comparison of the NMR data of $\mathbf{7}$ and $\mathbf{1 8}$ deduces that they share the same aglycone skeleton. According to its ${ }^{1} \mathrm{H}^{-1} \mathrm{H}$ COSY, HSQC, and HMBC spectra, the structure of 7 is confirmed. The chemical shifts of H-26a $(\delta 4.10)$ and H-26b $(\delta 3.49)(\Delta \mathrm{ab}>0.57)$ further confirm the C-25S configuration of 7. Finally, the structure of 7 is elucidated as $26-O-\beta$-D-glucopyranosyl-(25S)-5 $\beta$-furost-2 $\beta, 3 \beta, 26$-triol 3-O- $\alpha$-L-rhamnopyranosyl-(1 $\rightarrow 4)-\beta$-D-glucopyranoside, named allituberoside J.

Compound 8 has the same molecular formula of $\mathrm{C}_{45} \mathrm{H}_{76} \mathrm{O}_{19}$ as 7 determined by HR-ESI-MS together with its ${ }^{13} \mathrm{C}$ NMR data. The same ${ }^{13} \mathrm{C}$ NMR data suggests that 8 and 7 are $C-25 R / S$ isomers of each other. The chemical shifts of $\mathrm{H}-26 \mathrm{a}(\delta 3.95)$ and $\mathrm{H}-26 \mathrm{~b}(\delta 3.63)(\Delta \mathrm{ab}<0.48)$ exhibit that the $\mathrm{C}-25$ configuration is $R$. Consequently, the structure of $\mathbf{8}$ is elucidated as $26-O-\beta$-D-glucopyranosyl-( $25 R)-5 \beta$-furost- $2 \beta, 3 \beta, 26$-triol 3-O- $\alpha$-L-rhamnopyranosyl-( $1 \rightarrow 4)-\beta$-D-glucopyranoside, named allituberoside $\mathrm{H}$.

Compound 9 has a molecular formula of $\mathrm{C}_{45} \mathrm{H}_{76} \mathrm{O}_{20}$ as confirmed by HR-ESI-MS along with its ${ }^{13} \mathrm{C}$ NMR data (Table 2). The NMR data suggests that 9 has the identical aglycone structure but has different $\mathrm{C}-3$ sugar from 7. Analysis of the ${ }^{1} \mathrm{H}-{ }^{1} \mathrm{H}$ COSY spectrum allows to establish the structures of the two glucoses comprising of the C-3 sugar chain, and the HMBC correlation between $\delta 5.39\left(\mathrm{H}-1^{\prime \prime}\right)$ and $83.1\left(\mathrm{C}-2^{\prime}\right)$ confirm their connectivity. By detailed analyses of ${ }^{1} \mathrm{H}^{-1} \mathrm{H}$ COSY, HSQC, and HMBC spectra, the structure of 9 is further confirmed. The chemical shifts of $\mathrm{H}-26 \mathrm{a}(\delta 4.10)$ and $\mathrm{H}-26 \mathrm{~b}(\delta 3.50)(\Delta \mathrm{ab}>0.57)$ exhibit that the C-25S configuration. Consequently, the structure of 9 is elucidated as $26-O-\beta$-D-glucopyranosyl-(25R)-5 $\beta$-furost-2 $\beta, 3 \beta, 26$-triol 3-O- $\beta$-D-glucopyranosyl-( $1 \rightarrow 2)-\beta$-D-glucopyranoside, named allituberoside I.

Table 2. ${ }^{13} \mathrm{C}$ NMR data for $\mathbf{9}, \mathbf{1 0}$ and $22-26$ ( $\delta$ in pyridine- $\left.d_{5}\right)$.

\begin{tabular}{cccccccc}
\hline No. & $\mathbf{9}$ & $\mathbf{1 0}$ & $\mathbf{2 2}$ & $\mathbf{2 3}$ & $\mathbf{2 4}$ & $\mathbf{2 5}$ & $\mathbf{2 6}$ \\
\hline 1 & 40.3 & 40.0 & 30.9 & 40.4 & 45.9 & 45.9 & 45.9 \\
2 & 67.2 & 67.0 & 27.0 & 67.1 & 70.7 & 70.6 & 70.6 \\
3 & 81.7 & 80.1 & 75.3 & 81.1 & 85.4 & 85.0 & 85.1 \\
4 & 31.6 & 31.7 & 30.7 & 31.2 & 33.6 & 33.5 & 33.5 \\
5 & 36.5 & 36.4 & 36.7 & 32.1 & 44.6 & 44.6 & 44.6 \\
6 & 26.3 & 26.2 & 26.8 & 26.3 & 28.2 & 28.2 & 28.2 \\
7 & 26.8 & 26.8 & 26.8 & 26.8 & 32.1 & 32.1 & 32.1 \\
8 & 35.6 & 35.2 & 35.5 & 35.5 & 34.6 & 34.6 & 34.6 \\
9 & 41.5 & 36.9 & 40.3 & 41.4 & 54.4 & 54.4 & 54.4 \\
\hline
\end{tabular}


Table 2. Cont.

\begin{tabular}{|c|c|c|c|c|c|c|c|}
\hline No. & 9 & 10 & 22 & 23 & 24 & 25 & 26 \\
\hline 10 & 37.1 & 36.9 & 35.3 & 37.0 & 36.9 & 36.9 & 36.9 \\
\hline 11 & 21.4 & 40.5 & 21.2 & 21.3 & 21.4 & 21.5 & 21.5 \\
\hline 12 & 40.6 & 40.5 & 40.2 & 40.2 & 40.0 & 40.0 & 40.0 \\
\hline 13 & 41.2 & 43.8 & 40.9 & 40.8 & 40.7 & 40.8 & 40.8 \\
\hline 14 & 56.3 & 54.6 & 56.5 & 56.3 & 56.3 & 56.3 & 56.3 \\
\hline 15 & 32.4 & 34.4 & 32.2 & 32.1 & 32.3 & 32.3 & 32.3 \\
\hline 16 & 81.2 & 84.5 & 81.3 & 81.4 & 81.2 & 81.3 & 81.3 \\
\hline 17 & 64.0 & 64.6 & 62.9 & 63.0 & 62.9 & 62.9 & 62.9 \\
\hline 18 & 16.7 & 14.4 & 16.6 & 16.5 & 16.5 & 16.6 & 16.6 \\
\hline 19 & 23.8 & 23.8 & 24.0 & 23.9 & 13.5 & 13.6 & 13.6 \\
\hline 20 & 40.7 & 103.6 & 42.1 & 42.4 & 42.4 & 42.4 & 42.4 \\
\hline 21 & 16.5 & 11.8 & 15.1 & 14.9 & 14.8 & 14.8 & 14.8 \\
\hline 22 & 110.6 & 152.4 & 109.7 & 109.7 & 109.7 & 109.7 & 109.7 \\
\hline 23 & 37.3 & 31.4 & 31.6 & 27.1 & 27.1 & 27.1 & 27.1 \\
\hline 24 & 28.4 & 23.6 & 24.1 & 21.4 & 21.4 & 21.5 & 21.5 \\
\hline 25 & 34.5 & 33.7 & 39.2 & 33.5 & 33.5 & 33.5 & 33.5 \\
\hline 26 & 75.4 & 75.2 & 64.4 & 61.0 & 60.9 & 60.9 & 60.9 \\
\hline \multirow[t]{2}{*}{27} & 17.5 & 17.2 & 64.1 & 69.5 & 69.5 & 69.5 & 69.5 \\
\hline & 3-O-Glc & 3-O-Glc & 3-O-Glc & 3-O-Glc & 3-O-Glc & 3-O-Glc & 3-O-Glc \\
\hline $1^{\prime}$ & 102.7 & 104.0 & 101.9 & 102.3 & 101.2 & 100.8 & 100.5 \\
\hline $2^{\prime}$ & 83.1 & 75.4 & 82.8 & 82.3 & 78.1 & 77.9 & 77.8 \\
\hline $3^{\prime}$ & 78.1 & 76.6 & 77.1 & 77.1 & 79.6 & 78.0 & 76.5 \\
\hline $4^{\prime}$ & 71.4 & 78.1 & 77.3 & 77.3 & 71.9 & 78.5 & 81.4 \\
\hline $5^{\prime}$ & 78.4 & 77.5 & 76.4 & 76.3 & 78.4 & 77.2 & 77.3 \\
\hline \multirow[t]{2}{*}{$6^{\prime}$} & 62.4 & 61.3 & 61.3 & 61.0 & 62.5 & 61.1 & 61.5 \\
\hline & $2^{\prime}-\mathrm{O}-\mathrm{Glc}$ & $4^{\prime}$-O-Rha & $2^{\prime}-\mathrm{O}-\mathrm{Glc}$ & $2^{\prime}-\mathrm{O}-\mathrm{Glc}$ & $2^{\prime}$-O-Rha & $2^{\prime}-O-R h a$ & $2^{\prime}-\mathrm{O}-\mathrm{Rh} a$ \\
\hline $1^{\prime \prime}$ & 106.2 & 102.7 & 105.7 & 105.6 & 102.2 & 102.2 & 102.2 \\
\hline $2^{\prime \prime}$ & 77.1 & 72.7 & 77.1 & 77.0 & 72.5 & 72.5 & 72.4 \\
\hline $3^{\prime \prime}$ & 77.9 & 72.8 & 77.9 & 78.0 & 72.8 & 72.8 & 72.8 \\
\hline $4^{\prime \prime}$ & 71.8 & 74.0 & 71.8 & 71.9 & 74.2 & 74.1 & 74.1 \\
\hline $5^{\prime \prime}$ & 78.5 & 70.4 & 78.6 & 78.5 & 69.5 & 69.6 & 69.6 \\
\hline \multirow[t]{2}{*}{$6^{\prime \prime}$} & 62.8 & 18.6 & 63.2 & 62.9 & 18.6 & 18.6 & 18.6 \\
\hline & 26-O-Glc & 26-O-Glc & $4^{\prime}-O-R h a$ & $4^{\prime}$-O-Rha & 27-O-Glc & $4^{\prime}-O-$ Rha & $4^{\prime}-O-X y l$ \\
\hline $1^{\prime \prime \prime}$ & 105.2 & 105.2 & 102.4 & 102.4 & 105.0 & 103.0 & 105.8 \\
\hline $2^{\prime \prime \prime}$ & 75.3 & 75.0 & 72.6 & 72.5 & 75.3 & 72.6 & 75.4 \\
\hline $3^{\prime \prime \prime}$ & 78.7 & 78.6 & 72.8 & 72.8 & 78.6 & 72.8 & 78.4 \\
\hline $4^{\prime \prime \prime}$ & 71.7 & 71.7 & 74.0 & 74.0 & 71.8 & 74.0 & 70.8 \\
\hline $5^{\prime \prime \prime}$ & 78.6 & 78.6 & 70.3 & 70.3 & 78.6 & 70.5 & 67.4 \\
\hline \multirow[t]{2}{*}{$6^{\prime \prime \prime}$} & 62.8 & 62.8 & 18.5 & 18.6 & 62.8 & 18.5 & \\
\hline & & & & 27-O-Glc & & 27-O-Glc & 27-O-Glc \\
\hline $1^{\prime \prime \prime \prime}$ & & & & 105.0 & & 105.1 & 105.1 \\
\hline $2^{\prime \prime \prime \prime}$ & & & & 75.3 & & 75.4 & 75.0 \\
\hline $3^{\prime \prime \prime \prime \prime}$ & & & & 78.6 & & 78.7 & 78.6 \\
\hline $4^{\prime \prime \prime \prime \prime}$ & & & & 71.7 & & 71.8 & 71.8 \\
\hline $5^{\prime \prime \prime \prime}$ & & & & 78.6 & & 78.7 & 78.5 \\
\hline $6^{\prime \prime \prime \prime}$ & & & & 62.9 & & 62.8 & 62.8 \\
\hline
\end{tabular}

Compound 10 has a molecular formula of $\mathrm{C}_{45} \mathrm{H}_{74} \mathrm{O}_{18}$ as assigned by HR-ESI-MS. Its NMR data suggest that it shares the identical structure with 7 except for the differences surrounding the C-20 and C-22 positions. The characteristic carbon signals of $\delta 103.6$ and 152.4 indicate the existence of the $\Delta^{20(22)}$-ene substructures in the molecule. Detailed analysis of ${ }^{1} \mathrm{H}^{1} \mathrm{H}_{\mathrm{H}} \mathrm{COSY}, \mathrm{HSQC}$, and HMBC spectra allows the structure of $\mathbf{1 0}$ to be further confirmed. The chemical shifts of H-26a $(\delta 4.09)$ and $\mathrm{H}-26 \mathrm{~b}(\delta 3.49)(\Delta \mathrm{ab}>0.57)$ exhibit that the C-25S configuration of 10 . Thus, the structure of $\mathbf{1 0}$ is elucidated as $26-O-\beta$-D-glucopyranosyl-(25S)- $5 \beta$-furost- $\Delta^{20(22)}$-ene- $2 \alpha, 3 \beta$, 26-diol 3-O- $\alpha$-L-rhamnopyranosyl-( $1 \rightarrow 4)-\beta$-D-glucopyranoside, named allituberoside J. 
Compound 22 is isolated in the form of white powders with a molecular formula of $\mathrm{C}_{45} \mathrm{H}_{74} \mathrm{O}_{18}$ based on HR-ESI-MS and ${ }^{13} \mathrm{C}$ NMR data. In its ${ }^{1} \mathrm{H}$ NMR spectrum, the anomeric proton signals at $\delta$ $4.87(1 \mathrm{H}, \mathrm{d}, J=7.2 \mathrm{~Hz}), 5.93(1 \mathrm{H}, \mathrm{br} \mathrm{s})$, and $5.47(1 \mathrm{H}, \mathrm{d}, J=7.6 \mathrm{~Hz})$ suggest that 22 has three sugar units. Comparing the NMR data of 22 and 18 reveals that they share the same C-3 sugar chain together with the substructure of A-E rings. Only three typical methyl proton signals at $\delta 0.85(3 \mathrm{H}, \mathrm{s}), 0.97(3 \mathrm{H}, \mathrm{s})$, $1.18(3 \mathrm{H}, \mathrm{d}, J=6.8 \mathrm{~Hz})$ are observed in the ${ }^{1} \mathrm{H}$ NMR spectrum of 22 , and its ${ }^{13} \mathrm{C}$ NMR spectrum shows that the chemical shift of C-27 ( $\delta 64.1)$ shifted to a lower field, suggesting the linkage of hydroxyl group to the C-27. By further comparing the NMR data, it is deduced that 22 had the same F-ring structure as (25S)-27-hydroxypenogenin-3-O- $\alpha$-L-rhamnopyranosyl-( $\rightarrow \rightarrow 2)-O-\beta$-D-glucopyranoside [15].

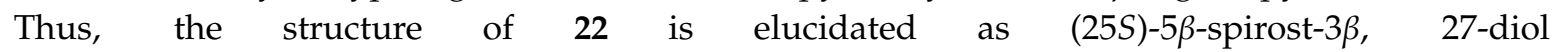
3-O- $\alpha$-L-rhamnopyranosyl- $(1 \rightarrow 4)$-[ $\beta$-D-glucopyranosyl-( $1 \rightarrow 2)]-\beta$-D-glucopyranoside, $\quad$ named allituberoside $\mathrm{K}$.

Compound 23 has a molecular formula of $\mathrm{C}_{51} \mathrm{H}_{84} \mathrm{O}_{24}$ as measured by HR-ESI-MS and ${ }^{13} \mathrm{C}$ NMR data. In the ${ }^{1} \mathrm{H}$ NMR spectrum, the anomeric proton signals at $\delta 4.94(2 \mathrm{H}, \mathrm{d}, J=7.8 \mathrm{~Hz})$, $5.45(1 \mathrm{H}, \mathrm{d}, J=7.6 \mathrm{~Hz})$, and $5.90(1 \mathrm{H}, \mathrm{br} \mathrm{s})$ suggest that it has four sugar units. According to its NMR data, 23 has the same C-3 sugar chain as 22, and shares the identical A-E rings substructure with 7-9. The ${ }^{1} \mathrm{H}$ NMR spectrum of 23 shows only three typical methyl proton signals at $\delta$ $0.78(3 \mathrm{H}, \mathrm{s}), 0.98(3 \mathrm{H}, \mathrm{s}), 1.09(3 \mathrm{H}, \mathrm{d}, J=6.8 \mathrm{~Hz})$, suggesting that its $\mathrm{C}-27$ is substituted by an additional glucose unit, and that is also supported by the HMBC correlations of $\delta 4.37(\mathrm{H}-27 \mathrm{a}), 3.94$ $(\mathrm{H}-27 \mathrm{~b}) / 21.4$ (C-24), 33.5 (C-25), 61.0 (C-26), and of $\delta 4.94\left(\mathrm{H}-1^{\prime \prime \prime \prime}\right) / 69.5$ (C-27). While the different NMR data of F-ring (C-22 C-27) between 23 and 27 suggest that they might have different C-25 configurations. The key carbon signals of $\delta 27.1$ (C-23), 21.4 (C-24), and 61.0 (C-26) which are in accordance with those of trikamsteroside $\mathrm{A}$ [27] suggest that the C-25 configuration of 23 to be $R$. Thus, the structure of 23 is elucidated as 27-O- $\beta$-D-glucopyranoside-(25R)-5 $\beta$-spirost-2 $\beta, 26,27-$ triol 3-O- $\alpha$-L-rhamnopyranosyl- $(1 \rightarrow 4)$-[ $\beta$-D-glucopyranosyl-( $1 \rightarrow 2)]-\beta$-D-glucopyranoside, named allituberoside L.

Compound 24 with a molecular formula of $\mathrm{C}_{45} \mathrm{H}_{74} \mathrm{O}_{19}$ as deduced by HR-ESI-MS and ${ }^{13} \mathrm{C}$ NMR data has the identical sugar chain at C-3 position and A-E rings substructure with 11-13 and shares the same F-ring including the 27-O- $\beta$-D-glucopyranose with 23 by comparing their NMR data. A detailed analysis of ${ }^{1} \mathrm{H}-{ }^{1} \mathrm{H}$ COSY, HSQC, and HMBC spectra allows the structure of 24 to be further confirmed as $27-O-\beta$-D-glucopyranoside-(25R)- $5 \alpha$-spirost-2 $\alpha, 26,27$-triol

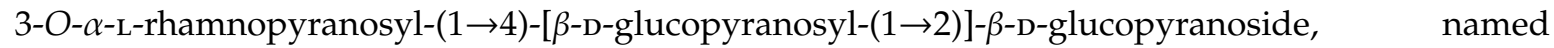
allituberoside $\mathrm{M}$.

Compound 25 has a molecular formula of $\mathrm{C}_{51} \mathrm{H}_{84} \mathrm{O}_{23}$ as determined by HR-ESI-MS and ${ }^{13} \mathrm{C}$ NMR data. The NMR data suggests that, except for the different sugar chain at C-3 position, it has the identical structure with 24. Comparison of NMR data further reveals that it has the same C-3 sugar chain as 27. Detailed analysis of ${ }^{1} \mathrm{H}^{-1} \mathrm{H}$ COSY, HSQC, and HMBC spectra finally confirms the structure of 25 to be $27-O-\beta$-D-glucopyranoside-(25R)- $5 \alpha$-spirost-2 $\alpha, 26,27-$ triol 3-O- $\alpha$-L-rhamnopyranosyl- $(1 \rightarrow 4)$-[ $\alpha$-L-rhamnopyranosyl- $(1 \rightarrow 2)]-\beta$-D-glucopyranoside, named allituberoside $\mathrm{N}$.

Compound 26 has a molecular formula of $\mathrm{C}_{50} \mathrm{H}_{82} \mathrm{O}_{23}$ as revealed according to HR-ESI-MS. Its NMR data suggests that $\mathbf{2 6}$ shares the identical structure with $\mathbf{2 4}$ except for the difference in structure of sugar chain at C-3. Further comparison of the NMR data reveals that the C-3 sugar chain of 26 is same as that of 3 . According to its ${ }^{1} \mathrm{H}_{-}{ }^{1} \mathrm{H}$ COSY, HSQC, and HMBC spectra data, the whole structure of $\mathbf{2 6}$ is finally confirmed. Therefore, the structure of $\mathbf{2 6}$ is confirmed to be $27-O-\beta$-D-glucopyranoside-(25R)- $5 \alpha$-spirost-2 $\alpha, 26,27$-triol 3-O- $\beta$-D-xylopyranosyl- $(1 \rightarrow 4)$-[ $\beta$-D-glucopyranosyl- $(1 \rightarrow 2)]-\beta$-D-glucopyranoside, named allituberoside $\mathrm{O}$.

An in vitro bioassay is carried out on compounds 1-27 for evaluating their promotional roles in testosterone production of rat Leydig cells. The results of $3 \beta-\mathrm{HSD}$ staining show that Leydig cells are 
successfully isolated from testes (Figure 2), with an approximate purity of ca. $90 \%$. After treatment with these compounds at $50 \mu \mathrm{M}$, the cell survival rates are higher than $80 \%$, suggesting that no compound exhibits the noticeable cytotoxic effect on the rat Leydig cells.
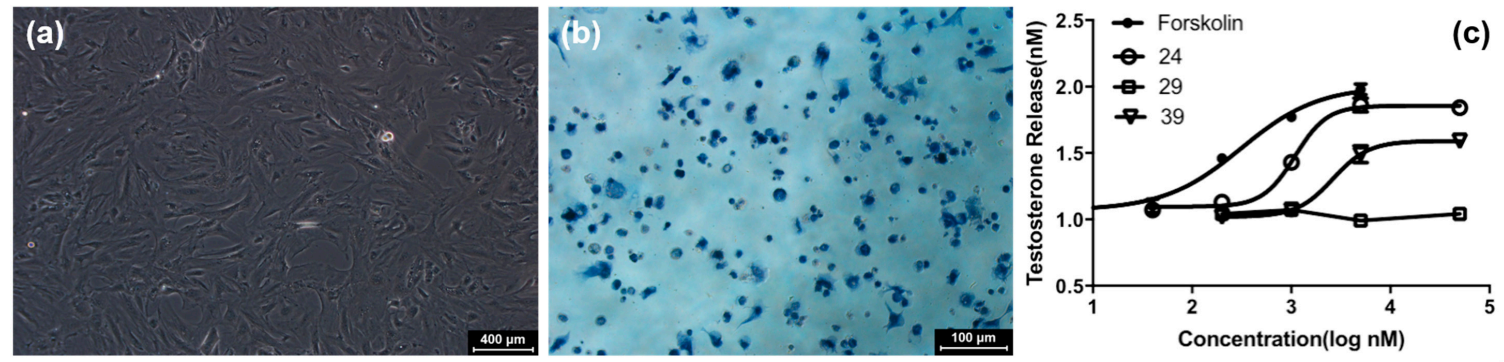

Figure 2. (a) Cell morphology of purified rat Leydig cells. (b) 3 $\beta$-HSD staining of purified rat Leydig cells. The positive cells were stained in dark blue color. (c) Effects of compounds 15, 21, and 26 on testosterone secretion in Leydig cells.

Exposure to forskolin results in a significant increase in levels of testosterone production in Leydig cells. Similarly, 1, 2, 7, 8, 10, 13-15, 20, 23, and 26 display a good role in increasing testosterone secretion with the $\mathrm{EC}_{50}$ values of 1.0 to $4.5 \mu \mathrm{M}$, respectively, and other compounds exhibit no significant activities $\left(\right.$ Each $\left.\mathrm{EC}_{50}>50 \mu \mathrm{M}\right)$ (Table 3 and Figure 2).

Table 3. Roles of compounds 1-27 in promoting testosterone production of rat Leydig cells.

\begin{tabular}{cccccccc}
\hline Compound & $\mathrm{EC}_{\mathbf{5 0}}(\boldsymbol{\mu M})$ & Compounds & $\mathrm{EC}_{\mathbf{5 0}}(\boldsymbol{\mu M})$ & Compound & $\mathrm{EC}_{\mathbf{5 0}}(\boldsymbol{\mu M})$ & Compounds & $\mathrm{EC}_{\mathbf{5 0}}(\boldsymbol{\mu M})$ \\
\hline $\mathbf{1}$ & 1.0 & $\mathbf{8}$ & 1.6 & $\mathbf{1 5}$ & 1.1 & $\mathbf{2 2}$ & $>50$ \\
$\mathbf{2}$ & 2.6 & $\mathbf{9}$ & $>50$ & $\mathbf{1 6}$ & $>50$ & $\mathbf{2 3}$ & 2.1 \\
$\mathbf{3}$ & $>50$ & $\mathbf{1 0}$ & 1.4 & $\mathbf{1 7}$ & $>50$ & $\mathbf{2 4}$ & $>50$ \\
$\mathbf{4}$ & $>50$ & $\mathbf{1 1}$ & $>50$ & $\mathbf{1 8}$ & $>50$ & $\mathbf{2 5}$ & $>50$ \\
$\mathbf{5}$ & $>50$ & $\mathbf{1 2}$ & 1.8 & $\mathbf{1 9}$ & $>50$ & $\mathbf{2 6}$ & 4.5 \\
$\mathbf{6}$ & $>50$ & $\mathbf{1 3}$ & 1.0 & $\mathbf{2 0}$ & 2.0 & $\mathbf{2 7}$ & $>50$ \\
$\mathbf{7}$ & 4.4 & $\mathbf{1 4}$ & 1.6 & $\mathbf{2 1}$ & $>50$ & Forskolin & 0.3 \\
\hline
\end{tabular}

\section{Materials and Methods}

\subsection{Experimental Procedures for Phytochmistry Study}

\subsubsection{General Experimental Procedures}

Optical rotations were recorded on a Rudolph Autopol ${ }^{\circledR}$ IV polarimeter. HR-ESI-MS was recorded on a Synapt MS (Waters Corporation, Milford, MA, USA). The NMR experiments were performed on Varian UNITY INOVA 600 spectrometer (600 MHz for ${ }^{1} \mathrm{H}$ NMR and $150 \mathrm{MHz}$ for ${ }^{13} \mathrm{C} \mathrm{NMR}$ ). The optical rotations were measured with a JASCO J-810 polarimeter. HPLC analysis is performed on an Agilent 1100 system equipped with an Alltech 2000 evaporative light scattering detector. Semi-preparative HPLC is performed on an NP7000 module (Hanbon Co. Ltd., Huaian, China) equipped with a Shodex RID 102 detector (Showa Denko Group, Tokyo, Japan). Silgreen HPLC C 18 columns $(4.6 / 10.0 \times 250 \mathrm{~mm}$, $5 \mu \mathrm{m}$, Silgreen Co. Ltd., Beijing, China) were used for HPLC and Semi-preparative HPLC. Silica gel H (Qingdao Marine Chemical, Qingdao, China), AB-8 macroporous adsorption resin (Solarbio, Beijing, China), SP825 macroporous adsorption resin (Mitsubishi Chemicals, Tokyo, Japan), MCI gel (Mitsubishi Chemicals, Tokyo, Japan), and ODS silica-gel (50 $\mu \mathrm{m}$, YMC, Kyoto, Japan) were applied for column chromatography. 


\subsubsection{Plant Material}

The dried ATSs were purchased from Shoguang City of Shandong Province in Oct 2018, and identified by Professor Baolin Guo (Institute of Medicinal Plant Development, Chinese Academy of Medical Sciences, Beijing, China). A voucher specimen was deposited in the authors' lab.

\subsubsection{Extraction and Isolation}

Allium tuberosum seeds (50 kg) were crushed and extracted with $70 \%$ aq. $\mathrm{CH}_{3} \mathrm{CH}_{2} \mathrm{OH}(400 \mathrm{~L})$ at reflux three times ( $1 \mathrm{~h}$ for each time). The filtered solution was concentrated in vacuo to get the supernatants and sediments. The supernatants were subjected to an AB-8 macroporous adsorption resin column eluted with $\mathrm{CH}_{3} \mathrm{CH}_{2} \mathrm{OH}-\mathrm{H}_{2} \mathrm{O}(v / v, 15: 85 \rightarrow 45: 55 \rightarrow 75: 25 \rightarrow 90: 10)$ to yield five fractions (Fr.A Fr.D). Fr.B were further subjected to a SP825 macroporous adsorption resin column eluted with $\mathrm{CH}_{3} \mathrm{CH}_{2} \mathrm{OH}-\mathrm{H}_{2} \mathrm{O}(v / v, 0: 100 \rightarrow 20: 80 \rightarrow 75: 25)$ to yield three fractions $\left(\mathrm{Fr} . \mathrm{B}_{1} \sim \mathrm{Fr} . \mathrm{B}_{3}\right)$. Fr. $\mathrm{B}_{3}$ was suspended with water and partitioned with ethyl acetate and butanol in turn to yield Fr. $B_{3}-\mathrm{A}$ and Fr. $B_{3}-B$. Fr. $B_{3}-B$ was subjected to silica-gel column chromatography eluted with a gradient mixture of $\mathrm{CHCl}_{3}-\mathrm{CH}_{3} \mathrm{OH}(v / v, 5: 1 \rightarrow 4: 1 \rightarrow 3: 1 \rightarrow 0: 100)$ to yield 66 subfractions $\left(\mathrm{Fr} \mathrm{B}_{3}-\mathrm{B}-\mathrm{S}_{1} \sim \mathrm{Fr} . \mathrm{B}_{3}-\mathrm{B}-\mathrm{S}_{66}\right)$. Fr. $B_{3}-\mathrm{B}-\mathrm{S}_{36-40}$ was subjected to ODS column chromatography eluted with $\mathrm{CH}_{3} \mathrm{OH}-\mathrm{H}_{2} \mathrm{O}(v / v, 60: 40)$ to afford 35 subfractions (Fr. B $3-B-S_{36}-40-\mathrm{O}_{1} \sim$ Fr. $\left.B_{3}-B_{-} S_{36}-40-\mathrm{O}_{35}\right)$. Among them, Fr. $B_{3}-B_{-}-S_{36}-40-\mathrm{O}_{16-17}$ was separated by semi-preparative HPLC with $\mathrm{CH}_{3} \mathrm{CN}-\mathrm{H}_{2} \mathrm{O}(v / v, 23: 77$, flowrate $4.0 \mathrm{~mL} / \mathrm{min})$ to afford 1 (12.5 mg); Fr. B $3-B-S_{36}-40-\mathrm{O}_{20-23}$ was separated by semi-preparative HPLC with $\mathrm{CH}_{3} \mathrm{CN}-\mathrm{H}_{2} \mathrm{O}(v / v$, 24:76, flowrate $4.0 \mathrm{~mL} / \mathrm{min})$ to afford 7 (225.7 mg), 8 (13.5 mg), and 11 (125.6 mg); Fr. B $3-B-S_{36}-40-\mathrm{O}_{30-34}$ was separated by semi-preparative $\mathrm{HPLC}$ with $\mathrm{CH}_{3} \mathrm{CN}-\mathrm{H}_{2} \mathrm{O}(v / v, 27: 73$, flowrate $4.0 \mathrm{~mL} / \mathrm{min})$ to afford 10 (78.5 mg); Fr. $\mathrm{B}_{3}-\mathrm{B}-\mathrm{S}_{36}-40-\mathrm{O}_{35-36}$ was separated by semi-preparative HPLC with $\mathrm{CH}_{3} \mathrm{CN}-\mathrm{H}_{2} \mathrm{O}$ $(v / v, 30: 70$, flowrate $4.0 \mathrm{~mL} / \mathrm{min})$ to afford $5(18.7 \mathrm{mg})$ and $22(4.5 \mathrm{mg})$. Fr.B ${ }_{3}-\mathrm{B}_{-} \mathrm{S}_{48-54}$ was subjected to ODS column chromatography eluted with methanol- $\mathrm{H}_{2} \mathrm{O}(v / v, 25: 75 \rightarrow 28: 72 \rightarrow 30: 70)$ to afford 30 subfractions (Fr. $\mathrm{B}_{3}-\mathrm{B}-\mathrm{S}_{48-54}-\mathrm{O}_{1} \sim \mathrm{Fr} . \mathrm{B}_{3}-\mathrm{B}-\mathrm{S}_{48-54}-\mathrm{O}_{30}$ ). Among them, Fr. $\mathrm{B}_{3}-\mathrm{B}-\mathrm{S}_{48-54}-\mathrm{O}_{6-8}$ was separated by semi-preparative HPLC with $\mathrm{CH}_{3} \mathrm{CN}-\mathrm{H}_{2} \mathrm{O}(\mathrm{v} / \mathrm{v}, 30: 70$, flowrate $4.0 \mathrm{~mL} / \mathrm{min})$ to afford $2(18.3 \mathrm{mg})$, 12 (122.6 mg), 13 (20.7 mg) and 24 (20.8 mg); Fr.B $3-B_{-} \mathrm{S}_{48}-54-\mathrm{O}_{18-20}$ was separated by semi-preparative HPLC with $\mathrm{CH}_{3} \mathrm{CN}-\mathrm{H}_{2} \mathrm{O}(v / v, 26: 74$, flowrate $4.0 \mathrm{~mL} / \mathrm{min})$ to afford $14(87.8 \mathrm{mg})$ and $20(18.4 \mathrm{mg})$; Fr. $B_{3}-\mathrm{B}-\mathrm{S}_{48-54}-\mathrm{O}_{26-29}$ was separated by semi-preparative $\mathrm{HPLC}$ with $\mathrm{CH}_{3} \mathrm{CN}-\mathrm{H}_{2} \mathrm{O}(v / v, 30: 70$, flowrate $4.0 \mathrm{~mL} / \mathrm{min})$ to afford $15(48.5 \mathrm{mg})$; Fr. $\mathrm{B}_{3}-\mathrm{B}_{-} \mathrm{S}_{48-54}-\mathrm{O}_{34-38}$ was separated by semi-preparative HPLC with $\mathrm{CH}_{3} \mathrm{CN}-\mathrm{H}_{2} \mathrm{O}(v / v, 30: 70$, flowrate $4.0 \mathrm{~mL} / \mathrm{min})$ to afford $17(84.2 \mathrm{mg})$ and 21 (13.0 mg). Fr.B 3 -B-S $55-65$ was subjected to ODS column chromatography eluted with $\mathrm{CH}_{3} \mathrm{OH}-\mathrm{H}_{2} \mathrm{O}(v / v, 23: 77 \rightarrow 30: 70)$ to afford 39 subfractions (Fr.B $\left.3-B_{-} \mathrm{S}_{55-65}-\mathrm{O}_{1} \sim \mathrm{Fr} . \mathrm{B}_{3}-\mathrm{B}_{-} \mathrm{S}_{55}-65-\mathrm{O}_{39}\right)$. Among them, Fr. $\mathrm{B}_{3}-\mathrm{B}-\mathrm{S}_{55-65}-\mathrm{O}_{7-9}$ was separated by semi-preparative HPLC with $\mathrm{CH}_{3} \mathrm{CN}-\mathrm{H}_{2} \mathrm{O}(v / v, 22: 78$, flowrate $4.0 \mathrm{~mL} / \mathrm{min})$ to afford $9(45.8 \mathrm{mg})$ and 18 (19.2 mg); Fr.B $3-B_{5}-\mathrm{S}_{55-65}-\mathrm{O}_{14-15}$ was separated by semi-preparative HPLC with $\mathrm{CH}_{3} \mathrm{CN}-\mathrm{H}_{2} \mathrm{O}$ $(v / v, 23: 77$, flowrate $4.0 \mathrm{~mL} / \mathrm{min})$ to afford 2 (53.3 mg), 3 (18.1 mg), 25 (25.6 mg), and 26 (49.6 mg); Fr. $\mathrm{B}_{3}-\mathrm{B}-\mathrm{S}_{55-65}-\mathrm{O}_{22-25}$ was separated by semi-preparative $\mathrm{HPLC}$ with $\mathrm{CH}_{3} \mathrm{CN}-\mathrm{H}_{2} \mathrm{O}(v / v, 24: 76$, flowrate $4.0 \mathrm{~mL} / \mathrm{min})$ to afford $18(134.5 \mathrm{mg}), 19(16.5 \mathrm{mg})$, and $27(18.3 \mathrm{mg}) ; \mathrm{Fr} \mathrm{B}_{3}-\mathrm{B}-\mathrm{S}_{55-65}-\mathrm{O}_{33}$ was separated by semi-preparative HPLC with $\mathrm{CH}_{3} \mathrm{CN}-\mathrm{H}_{2} \mathrm{O}(v / v, 25: 75$, flowrate $4.0 \mathrm{~mL} / \mathrm{min})$ to afford $14(25.6$ $\mathrm{mg})$; Fr. $\mathrm{B}_{3}-\mathrm{B}_{-} \mathrm{S}_{55-65}-\mathrm{O}_{34-37}$ was separated by semi-preparative HPLC with $\mathrm{CH}_{3} \mathrm{OH}-\mathrm{H}_{2} \mathrm{O}(v / v, 60: 40$, flowrate $4.0 \mathrm{~mL} / \mathrm{min})$ to afford $4(9.4 \mathrm{mg}), \mathbf{6}(7.2 \mathrm{mg})$, and $16(36.5 \mathrm{mg})$. Fr. $\mathrm{B}_{3}-\mathrm{B}_{-} \mathrm{S}_{66}$ was subjected to ODS column chromatography eluted with $\mathrm{CH}_{3} \mathrm{OH}-\mathrm{H}_{2} \mathrm{O}(v / v, 40: 60 \rightarrow 60: 40)$ to afford 7 subfractions (Fr. $\mathrm{B}_{3}-\mathrm{B}-\mathrm{S}_{66}-\mathrm{O}_{1} \sim$ Fr. $\left.\mathrm{B}_{3}-\mathrm{B}-\mathrm{S}_{66}-\mathrm{O}_{7}\right)$. Among them, Fr. $\mathrm{B}_{3}-\mathrm{B}-\mathrm{S}_{66}-\mathrm{O}_{4}$ was separated by semi-preparative HPLC with $\mathrm{CH}_{3} \mathrm{CN}-\mathrm{H}_{2} \mathrm{O}(v / v, 22: 78$, flowrate $4.0 \mathrm{~mL} / \mathrm{min})$ to afford 23 (14.0 $\left.\mathrm{mg}\right)$.

Allituberoside A (1): $\mathrm{C}_{39} \mathrm{H}_{66} \mathrm{O}_{16}$; white amorphous powder; $[\alpha]_{\mathrm{D}}^{25}-44.4\left(c 0.036, \mathrm{CH}_{3} \mathrm{OH}\right) ;{ }^{1} \mathrm{H}$ NMR (600 MHz, pyridine- $\left.d_{5}\right) \delta 4.71(1 \mathrm{H}, \mathrm{m}, \mathrm{H}-3), 0.88(3 \mathrm{H}, \mathrm{s}, \mathrm{H}-18), 1.17(3 \mathrm{H}, \mathrm{s}, \mathrm{H}-19), 1.33$ (3H, d, $J=6.8 \mathrm{~Hz}, \mathrm{H}-21), 4.09(1 \mathrm{H}$, overlap, H-26-Ha), $3.50(1 \mathrm{H}, \mathrm{dd}, J=8.9,7.3 \mathrm{~Hz}, \mathrm{H}-26-\mathrm{Hb}), 1.05(3 \mathrm{H}, \mathrm{d}$, $J=7.0 \mathrm{~Hz}, \mathrm{H}-27), 5.11\left(1 \mathrm{H}, \mathrm{d}, J=7.8 \mathrm{~Hz}, \mathrm{H}-1^{\prime}\right.$ of $\left.3-\mathrm{O}-\mathrm{Glc}\right), 4.83\left(1 \mathrm{H}, \mathrm{d}, J=7.8 \mathrm{~Hz}, \mathrm{H}-1^{\prime \prime}\right.$ of 26-O-Glc); ${ }^{13} \mathrm{C}$ NMR (150 MHz, pyridine- $d_{5}$ ) spectroscopic data see Table 1; HR-ESI-MS m/z $789.4272[\mathrm{M}-\mathrm{H}]^{-}$ (calcd. for $\mathrm{C}_{39} \mathrm{H}_{65} \mathrm{O}_{16}, 789.4273$ ). 
Allituberoside B (2): $\mathrm{C}_{51} \mathrm{H}_{86} \mathrm{O}_{23}$; white amorphous powder; $[\alpha]_{\mathrm{D}}^{25}-78.5\left(c 0.028, \mathrm{CH}_{3} \mathrm{OH}\right) ;{ }^{1} \mathrm{H}$ NMR (600 MHz, pyridine- $\left.d_{5}\right): \delta 3.89(1 \mathrm{H}, \mathrm{m}, \mathrm{H}-3), 0.87(3 \mathrm{H}, \mathrm{s}, \mathrm{H}-18), 0.90(3 \mathrm{H}, \mathrm{s}, \mathrm{H}-19), 1.31(3 \mathrm{H}, \mathrm{d}$, $J=6.7 \mathrm{~Hz}, \mathrm{H}-21), 4.10(1 \mathrm{H}$, overlap, H-26-Ha), $3.49(1 \mathrm{H}, \mathrm{dd}, J=9.0,7.2 \mathrm{~Hz}, \mathrm{H}-26-\mathrm{Hb}), 1.03(3 \mathrm{H}, \mathrm{d}$, $J=7.0 \mathrm{~Hz}, \mathrm{H}-27), 5.03\left(1 \mathrm{H}, \mathrm{d}, J=7.1 \mathrm{~Hz}, \mathrm{H}-1^{\prime}\right.$ of $\left.3-\mathrm{O}-\mathrm{Glc}\right), 6.40\left(1 \mathrm{H}, \mathrm{br} \mathrm{s}, \mathrm{H}-1^{\prime \prime}\right.$ of $\left.2^{\prime}-\mathrm{O}-\mathrm{Rha}\right), 5.86(1 \mathrm{H}, \mathrm{br}$ $\mathrm{s}, \mathrm{H}-1^{\prime \prime \prime}$ of $\left.4^{\prime}-\mathrm{O}-\mathrm{Rha}\right), 4.82\left(1 \mathrm{H}, \mathrm{d}, J=7.8 \mathrm{~Hz}, \mathrm{H}-1^{\prime \prime \prime \prime}\right.$ of $\left.26-\mathrm{O}-\mathrm{Glc}\right) ;{ }^{13} \mathrm{C}$ NMR $\left(150 \mathrm{MHz}\right.$, pyridine- $\left.d_{5}\right)$ spectroscopic data see Table 1; HR-ESI-MS: $m / z 1065.5466[\mathrm{M}-\mathrm{H}]^{-}$(calcd. for $\mathrm{C}_{51} \mathrm{H}_{85} \mathrm{O}_{23}, 1065.5482$ ).

Allituberoside $\mathrm{C}(3)$ : $\mathrm{C}_{50} \mathrm{H}_{84} \mathrm{O}_{23}$; white amorphous powder; $[\alpha]_{\mathrm{D}}^{25}-70.3\left(c 0.037, \mathrm{CH}_{3} \mathrm{OH}\right) ;{ }^{1} \mathrm{H}$ NMR (600 MHz, pyridine- $\left.d_{5}\right) \delta 3.88(1 \mathrm{H}, \mathrm{m}, \mathrm{H}-3), 0.87(3 \mathrm{H}, \mathrm{s}, \mathrm{H}-18), 0.91(3 \mathrm{H}, \mathrm{s}, \mathrm{H}-19), 1.31(3 \mathrm{H}, \mathrm{d}$, $J=6.8 \mathrm{~Hz}, \mathrm{H}-21), 4.11(1 \mathrm{H}$, overlap, H-26-Ha), $3.49(1 \mathrm{H}, \mathrm{dd}, J=9.2,7.1 \mathrm{~Hz}, \mathrm{H}-26-\mathrm{Hb}), 1.03(3 \mathrm{H}, \mathrm{d}$, $J=6.6 \mathrm{~Hz}, \mathrm{H}-27), 5.03\left(1 \mathrm{H}, \mathrm{d}, J=7.9 \mathrm{~Hz}, \mathrm{H}-1^{\prime}\right.$ of $\left.3-\mathrm{O}-\mathrm{Glc}\right), 6.26\left(1 \mathrm{H}, \mathrm{br} \mathrm{s}, \mathrm{H}-1^{\prime \prime}\right.$ of 2'-O-Rha), $5.04(1 \mathrm{H}$, $\mathrm{d}, J=7.8 \mathrm{~Hz}, \mathrm{H}-1^{\prime \prime \prime}$ of $\left.4^{\prime}-\mathrm{O}-\mathrm{Xyl}\right), 4.82\left(1 \mathrm{H}, \mathrm{d}, J=8.0 \mathrm{~Hz}, \mathrm{H}-1^{\prime \prime \prime \prime}\right.$ of $\left.26-\mathrm{O}-\mathrm{Glc}\right) ;{ }^{13} \mathrm{C} \mathrm{NMR}(150 \mathrm{MHz}$, pyridine- $d_{5}$ ) spectroscopic data see Table 1; HR-ESI-MS m/z $1051.5316[\mathrm{M}-\mathrm{H}]^{-}$(calcd. for $\mathrm{C}_{50} \mathrm{H}_{83} \mathrm{O}_{23}$, 1051.5325).

Allituberoside D (4): $\mathrm{C}_{50} \mathrm{H}_{82} \mathrm{O}_{22}$; white amorphous powder; $[\alpha]_{\mathrm{D}}^{25}-75.2\left(c 0.028, \mathrm{CH}_{3} \mathrm{OH}\right) ;{ }^{1} \mathrm{H}$ NMR $\left(600 \mathrm{MHz}\right.$, pyridine- $\left.d_{5}\right) \delta 3.88(1 \mathrm{H}, \mathrm{m}, \mathrm{H}-3), 0.68(3 \mathrm{H}, \mathrm{s}, \mathrm{H}-18), 0.92(3 \mathrm{H}, \mathrm{s}, \mathrm{H}-19), 1.62(3 \mathrm{H}, \mathrm{s}$, $\mathrm{H}-21), 4.10(1 \mathrm{H}$, overlap, H-26-Ha), $3.49(1 \mathrm{H}, \mathrm{dd}, J=9.1,7.1 \mathrm{~Hz}, \mathrm{H}-26-\mathrm{Hb}), 1.04(3 \mathrm{H}, \mathrm{d}, J=6.7 \mathrm{~Hz}$, $\mathrm{H}-27), 5.04\left(1 \mathrm{H}, \mathrm{d}, J=7.4 \mathrm{~Hz}, \mathrm{H}-1^{\prime}\right.$ of $\left.3-\mathrm{O}-\mathrm{Glc}\right), 6.27\left(1 \mathrm{H}, \mathrm{br} \mathrm{s}, \mathrm{H}-1^{\prime \prime}\right.$ of $\left.2^{\prime}-\mathrm{O}-\mathrm{Rha}\right), 5.05(1 \mathrm{H}, \mathrm{d}, J=7.8$ $\mathrm{Hz}, \mathrm{H}-1^{\prime \prime \prime}$ of $\left.4^{\prime}-\mathrm{O}-\mathrm{Xyl}\right), 4.85$ (1H, d, $J=7.7 \mathrm{~Hz}, \mathrm{H}-1^{\prime \prime \prime \prime}$ of $\left.26-\mathrm{O}-\mathrm{Glc}\right) ;{ }^{13} \mathrm{C}$ NMR (150 MHz, pyridine- $\left.d_{5}\right)$ spectroscopic data see Table 1; HR-ESI-MS $m / z 1033.5208[\mathrm{M}-\mathrm{H}]^{-}$(calcd. for $\mathrm{C}_{50} \mathrm{H}_{81} \mathrm{O}_{22}, 1033.5219$ ).

Allituberoside $\mathrm{E}$ (5): $\mathrm{C}_{45} \mathrm{H}_{74} \mathrm{O}_{18}$; white amorphous powder; $[\alpha]_{\mathrm{D}}^{25}-66.7\left(c 0.024, \mathrm{CH}_{3} \mathrm{OH}\right) ;{ }^{1} \mathrm{H}$ NMR $\left(600 \mathrm{MHz}\right.$, pyridine- $\left.d_{5}\right) \delta 3.86(1 \mathrm{H}, \mathrm{m}, \mathrm{H}-3), 0.69(3 \mathrm{H}, \mathrm{s}, \mathrm{H}-18), 0.75(3 \mathrm{H}, \mathrm{s}, \mathrm{H}-19), 1.62(3 \mathrm{H}, \mathrm{s}$, H-21), $4.10(1 \mathrm{H}$, overlap, H-26-Ha), 3.49 (1H, dd, $J=9.1,7.1 \mathrm{~Hz}, \mathrm{H}-26-\mathrm{Hb}), 1.04(3 \mathrm{H}, \mathrm{d}, J=6.7 \mathrm{~Hz}, \mathrm{H}-27)$, $5.04\left(1 \mathrm{H}, \mathrm{d}, J=7.9 \mathrm{~Hz}, \mathrm{H}-1^{\prime}\right.$ of $\left.3-\mathrm{O}-\mathrm{Glc}\right), 5.92\left(1 \mathrm{H}, \mathrm{br} \mathrm{s}, \mathrm{H}-1^{\prime \prime}\right.$ of $\left.2^{\prime}-\mathrm{O}-\mathrm{Rha}\right), 4.85\left(1 \mathrm{H}, \mathrm{d}, J=7.7 \mathrm{~Hz}, \mathrm{H}-1^{\prime \prime \prime}\right.$ of 26-O-Glc); ${ }^{13} \mathrm{C}$ NMR (150 MHz, pyridine- $\left.d_{5}\right)$ spectroscopic data see Table 1; HR-ESI-MS m/z 901.4807 $[\mathrm{M}-\mathrm{H}]^{-}$(calcd. for $\mathrm{C}_{45} \mathrm{H}_{73} \mathrm{O}_{18}, 901.4797$ ).

Allituberoside $\mathrm{F}(6)$ : $\mathrm{C}_{51} \mathrm{H}_{84} \mathrm{O}_{22}$; white amorphous powder; $[\alpha]_{\mathrm{D}}^{25}-70.8\left(c 0.030, \mathrm{CH}_{3} \mathrm{OH}\right) ;{ }^{1} \mathrm{H}$ NMR (600 MHz, pyridine- $\left.d_{5}\right) \delta 3.89(1 \mathrm{H}, \mathrm{m}, \mathrm{H}-3), 0.70(3 \mathrm{H}, \mathrm{s}, \mathrm{H}-18), 0.91(3 \mathrm{H}, \mathrm{s}, \mathrm{H}-19), 1.63(3 \mathrm{H}, \mathrm{d}$, $J=6.7 \mathrm{~Hz}, \mathrm{H}-21), 3.96(1 \mathrm{H}, \mathrm{dd}, J=9.1,7.9 \mathrm{~Hz}, \mathrm{H}-26-\mathrm{Ha}), 3.63(1 \mathrm{H}, \mathrm{dd}, J=9.4,5.8 \mathrm{~Hz}, \mathrm{H}-26-\mathrm{Hb}), 1.03$ $(3 \mathrm{H}, \mathrm{d}, J=7.0 \mathrm{~Hz}, \mathrm{H}-27), 5.03\left(1 \mathrm{H}, \mathrm{d}, J=6.8 \mathrm{~Hz}, \mathrm{H}-1^{\prime}\right.$ of $\left.3-\mathrm{O}-\mathrm{Glc}\right), 6.41\left(1 \mathrm{H}, \mathrm{br} \mathrm{s}, \mathrm{H}-1^{\prime \prime}\right.$ of 2'-O-Rha), $5.87\left(1 \mathrm{H}, \mathrm{br} \mathrm{s}, \mathrm{H}-1^{\prime \prime \prime}\right.$ of $\left.4^{\prime}-\mathrm{O}-\mathrm{Rha}\right), 4.86\left(1 \mathrm{H}, \mathrm{d}, J=8.0 \mathrm{~Hz}, \mathrm{H}-1^{\prime \prime \prime \prime}\right.$ of $\left.26-\mathrm{O}-\mathrm{Glc}\right) ;{ }^{13} \mathrm{C} \mathrm{NMR}(150 \mathrm{MHz}$, pyridine- $d_{5}$ ) spectroscopic data see Table 1; HR-ESI-MS $m / z 1047.5400[\mathrm{M}-\mathrm{H}]^{-}$(calcd. for $\mathrm{C}_{51} \mathrm{H}_{83} \mathrm{O}_{22}$, 1047.5376).

Allituberoside $\mathrm{G}(7): \mathrm{C}_{45} \mathrm{H}_{76} \mathrm{O}_{19}$; white amorphous powder; $[\alpha]_{D}^{25}-69.0\left(c 0.029, \mathrm{CH}_{3} \mathrm{OH}\right) ;{ }^{1} \mathrm{H}$ NMR (600 MHz, pyridine- $\left.d_{5}\right): \delta 3.90(1 \mathrm{H}, \mathrm{m}, \mathrm{H}-3), 0.87(3 \mathrm{H}, \mathrm{s}, \mathrm{H}-18), 0.85(3 \mathrm{H}, \mathrm{s}, \mathrm{H}-19), 1.33(3 \mathrm{H}, \mathrm{d}$, $J=6.8 \mathrm{~Hz}, \mathrm{H}-21), 4.10(1 \mathrm{H}, \mathrm{dd}, J=9.4,5.8 \mathrm{~Hz}, \mathrm{H}-26-\mathrm{Ha}), 3.49(1 \mathrm{H}, \mathrm{dd}, J=9.2,7.1 \mathrm{~Hz}, \mathrm{H}-26-\mathrm{Hb}), 1.04$ $(3 \mathrm{H}, \mathrm{d}, J=6.7 \mathrm{~Hz}, \mathrm{H}-27), 4.94\left(1 \mathrm{H}, \mathrm{d}, J=7.9 \mathrm{~Hz}, \mathrm{H}-1^{\prime}\right.$ of $\left.3-\mathrm{O}-\mathrm{Glc}\right), 5.92\left(1 \mathrm{H}, \mathrm{br} \mathrm{s}, \mathrm{H}-1^{\prime \prime}\right.$ of $\left.4^{\prime}-\mathrm{O}-\mathrm{Rha}\right), 4.83$ $\left(1 \mathrm{H}, \mathrm{d}, J=7.8 \mathrm{~Hz}, \mathrm{H}-1^{\prime \prime}\right.$ of $\left.26-\mathrm{O}-\mathrm{Glc}\right) ;{ }^{13} \mathrm{C}$ NMR $\left(150 \mathrm{MHz}\right.$, pyridine- $\left.d_{5}\right)$ spectroscopic data see Table 1 ; HR-ESI-MS $m / z 919.4893$ [M - H] ${ }^{-}$(calcd. for $\mathrm{C}_{45} \mathrm{H}_{75} \mathrm{O}_{19}, 919.4903$ ).

Allituberoside $\mathrm{H}(8): \mathrm{C}_{45} \mathrm{H}_{76} \mathrm{O}_{19}$; white amorphous powder; $[\alpha]_{\mathrm{D}}^{25}-88.0\left(c 0.025, \mathrm{CH}_{3} \mathrm{OH}\right) ;{ }^{1} \mathrm{H}$ NMR $\left(600 \mathrm{MHz}\right.$, pyridine- $\left.d_{5}\right) \delta 3.90(1 \mathrm{H}, \mathrm{m}, \mathrm{H}-3), 0.87(3 \mathrm{H}, \mathrm{s}, \mathrm{H}-18), 0.85(3 \mathrm{H}, \mathrm{s}, \mathrm{H}-19), 1.34(3 \mathrm{H}, \mathrm{d}$, $J=6.4 \mathrm{~Hz}, \mathrm{H}-21), 3.95(1 \mathrm{H}$, overlap, H-26-Ha), $3.63(1 \mathrm{H}, \mathrm{dd}, J=9.4,6.0 \mathrm{~Hz}, \mathrm{H}-26-\mathrm{Hb}), 1.04(3 \mathrm{H}, \mathrm{d}$, $J=6.7 \mathrm{~Hz}, \mathrm{H}-27), 4.94\left(1 \mathrm{H}, \mathrm{d}, J=7.9 \mathrm{~Hz}, \mathrm{H}-1^{\prime}\right.$ of $\left.3-\mathrm{O}-\mathrm{Glc}\right), 5.92\left(1 \mathrm{H}, \mathrm{br} \mathrm{s}, \mathrm{H}-1^{\prime \prime}\right.$ of $\left.4^{\prime}-\mathrm{O}-\mathrm{Rha}\right), 4.84(1 \mathrm{H}$, $\mathrm{d}, J=7.8 \mathrm{~Hz}, \mathrm{H}-1^{\prime \prime \prime}$ of $\left.26-\mathrm{O}-\mathrm{Glc}\right){ }^{13} \mathrm{C}$ NMR $\left(150 \mathrm{MHz}\right.$, pyridine- $\left.d_{5}\right)$ spectroscopic data see Table 1 ; HR-ESI-MS $m / z$ 919.4892 [M - H] ${ }^{-}$(calcd. for $\mathrm{C}_{45} \mathrm{H}_{75} \mathrm{O}_{19}$, 919.4903).

Allituberoside I (9): $\mathrm{C}_{45} \mathrm{H}_{76} \mathrm{O}_{20}$; white amorphous powder; $[\alpha]_{\mathrm{D}}^{25}-47.4\left(c 0.038, \mathrm{CH}_{3} \mathrm{OH}\right) ;{ }^{1} \mathrm{H}$ NMR $\left(600 \mathrm{MHz}\right.$, pyridine- $\left.d_{5}\right) \delta 4.26(1 \mathrm{H}, \mathrm{m}, \mathrm{H}-3), 0.87(3 \mathrm{H}, \mathrm{s}, \mathrm{H}-18), 1.00(3 \mathrm{H}, \mathrm{s}, \mathrm{H}-19), 1.32(3 \mathrm{H}, \mathrm{d}$, $J=6.8 \mathrm{~Hz}, \mathrm{H}-21), 4.10(1 \mathrm{H}$, overlap, $\mathrm{H}-26-\mathrm{Ha}), 3.50(1 \mathrm{H}, \mathrm{dd}, J=9.2,7.1 \mathrm{~Hz}, \mathrm{H}-26-\mathrm{Hb}), 1.04(3 \mathrm{H}, \mathrm{d}$, $J=6.6 \mathrm{~Hz}, \mathrm{H}-27), 5.04\left(1 \mathrm{H}, \mathrm{d}, J=7.8 \mathrm{~Hz}, \mathrm{H}-1^{\prime}\right.$ of $\left.3-\mathrm{O}-\mathrm{Glc}\right), 5.39\left(1 \mathrm{H}, \mathrm{d}, J=7.6 \mathrm{~Hz}, \mathrm{H}-1^{\prime \prime}\right.$ of 2'-O-Glc), $4.83\left(1 \mathrm{H}, \mathrm{d}, J=7.8 \mathrm{~Hz}, \mathrm{H}-1^{\prime \prime \prime}\right.$ of $\left.26-\mathrm{O}-\mathrm{Glc}\right) ;{ }^{13} \mathrm{C} \mathrm{NMR}\left(150 \mathrm{MHz}\right.$, pyridine- $\left.d_{5}\right)$ spectroscopic data see Table 2; HR-ESI-MS m/z 935.4837 [M - H] ${ }^{-}$(calcd. for $\mathrm{C}_{45} \mathrm{H}_{75} \mathrm{O}_{20}, 935.4852$ ). 
Allituberoside J (10): $\mathrm{C}_{45} \mathrm{H}_{74} \mathrm{O}_{18}$; white amorphous powder; $[\alpha]_{\mathrm{D}}^{25}-51.6\left(c 0.031, \mathrm{CH}_{3} \mathrm{OH}\right) ;{ }^{1} \mathrm{H}$ NMR (600 MHz, pyridine- $\left.d_{5}\right) \delta 4.47(1 \mathrm{H}, \mathrm{m}, \mathrm{H}-3), 0.68(3 \mathrm{H}, \mathrm{s}, \mathrm{H}-18), 0.87(3 \mathrm{H}, \mathrm{s}, \mathrm{H}-19), 1.62(3 \mathrm{H}, \mathrm{d}$, $J=6.8 \mathrm{~Hz}, \mathrm{H}-21), 4.09(1 \mathrm{H}, \mathrm{dd}, J=9.3,5.8 \mathrm{~Hz}, \mathrm{H}-26-\mathrm{Ha}), 3.49(1 \mathrm{H}, \mathrm{dd}, J=9.2,7.1 \mathrm{~Hz}, \mathrm{H}-26-\mathrm{Hb}), 1.04$ $(3 \mathrm{H}, \mathrm{d}, J=6.6 \mathrm{~Hz}, \mathrm{H}-27), 4.96\left(1 \mathrm{H}, \mathrm{d}, J=7.8 \mathrm{~Hz}, \mathrm{H}-1^{\prime}\right.$ of $\left.3-\mathrm{O}-\mathrm{Glc}\right), 5.93\left(1 \mathrm{H}, \mathrm{d}, J=7.6 \mathrm{~Hz}, \mathrm{H}-1^{\prime \prime}\right.$ of $4^{\prime}$-O-Rha), $4.86\left(1 \mathrm{H}, \mathrm{d}, J=7.6 \mathrm{~Hz}, \mathrm{H}-1^{\prime \prime \prime}\right.$ of $\left.26-\mathrm{O}-\mathrm{Glc}\right) ;{ }^{13} \mathrm{C}$ NMR $\left(150 \mathrm{MHz}\right.$, pyridine- $\left.d_{5}\right)$ spectroscopic data see Table 2; HR-ESI-MS $m / z$ 901.4787 [M - H] $]^{-}$(calcd. for $\mathrm{C}_{45} \mathrm{H}_{73} \mathrm{O}_{18}, 901.4797$ ).

Allituberoside $\mathrm{K}$ (22): $\mathrm{C}_{45} \mathrm{H}_{74} \mathrm{O}_{18}$; white amorphous powder; $[\alpha]_{\mathrm{D}}^{25}-99.3\left(c 0.025, \mathrm{CH}_{3} \mathrm{OH}\right) ;{ }^{1} \mathrm{H}$ NMR (600 MHz, pyridine- $\left.d_{5}\right) \delta 4.26(1 \mathrm{H}, \mathrm{m}, \mathrm{H}-3), 0.85(3 \mathrm{H}, \mathrm{s}, \mathrm{H}-18), 0.97(3 \mathrm{H}, \mathrm{s}, \mathrm{H}-19), 1.18(3 \mathrm{H}, \mathrm{d}$, $J=6.8 \mathrm{~Hz}, \mathrm{H}-21), 4.17(1 \mathrm{H}, \mathrm{dd}, J=10.6,3.8 \mathrm{~Hz}, \mathrm{H}-27-\mathrm{Ha}), 3.93(1 \mathrm{H}, \mathrm{t}, J=11.1 \mathrm{~Hz}, \mathrm{H}-27-\mathrm{Hb}), 4.87(1 \mathrm{H}, \mathrm{d}$, $J=7.2 \mathrm{~Hz}, \mathrm{H}-1^{\prime}$ of $\left.3-\mathrm{O}-\mathrm{Glc}\right), 5.47\left(1 \mathrm{H}, \mathrm{d}, J=7.6 \mathrm{~Hz}, \mathrm{H}-1^{\prime \prime}\right.$ of $\left.2^{\prime}-\mathrm{O}-\mathrm{Glc}\right), 5.93\left(1 \mathrm{H}, \mathrm{br} \mathrm{s}, \mathrm{H}-1^{\prime \prime \prime}\right.$ of $\left.4^{\prime}-\mathrm{O}-\mathrm{Rha}\right)$; ${ }^{13} \mathrm{C}$ NMR (150 MHz, pyridine- $\left.d_{5}\right)$ spectroscopic data see Table 2; HR-ESI-MS m/z $901.4800[\mathrm{M}-\mathrm{H}]^{-}$ (calcd. for $\mathrm{C}_{45} \mathrm{H}_{73} \mathrm{O}_{18}, 901.4797$ ).

Allituberoside $\mathrm{L}$ (23): $\mathrm{C}_{51} \mathrm{H}_{84} \mathrm{O}_{24}$; white amorphous powder; $[\alpha]_{\mathrm{D}}^{25}-108.3\left(c=0.024, \mathrm{CH}_{3} \mathrm{OH}\right) ;{ }^{1} \mathrm{H}$ NMR $\left(600 \mathrm{MHz}\right.$, pyridine- $\left.d_{5}\right) \delta 4.27(1 \mathrm{H}, \mathrm{m}, \mathrm{H}-3), 0.78(3 \mathrm{H}, \mathrm{s}, \mathrm{H}-18), 0.98(3 \mathrm{H}, \mathrm{s}, \mathrm{H}-19), 1.09(3 \mathrm{H}, \mathrm{d}$, $J=6.8 \mathrm{~Hz}, \mathrm{H}-21), 4.37(1 \mathrm{H}$, overlap, $\mathrm{H}-27-\mathrm{Ha}), 3.94(1 \mathrm{H}, \mathrm{t}, J=8.5 \mathrm{~Hz}, \mathrm{H}-27-\mathrm{Hb}), 4.94(1 \mathrm{H}, \mathrm{d}, J=7.8 \mathrm{~Hz}$, $\mathrm{H}-1^{\prime}$ of 3-O-Glc), $5.45\left(1 \mathrm{H}, \mathrm{d}, J=7.6 \mathrm{~Hz}, \mathrm{H}-1^{\prime \prime}\right.$ of $\left.2^{\prime}-\mathrm{O}-\mathrm{Glc}\right), 5.90\left(1 \mathrm{H}, \mathrm{br} \mathrm{s}, \mathrm{H}-1^{\prime \prime \prime}\right.$ of $\left.4^{\prime}-\mathrm{O}-\mathrm{Rha}\right), 4.94(1 \mathrm{H}$, $\mathrm{d}, J=7.8 \mathrm{~Hz}, \mathrm{H}-1^{\prime \prime \prime \prime}$ of $\left.27-O-G l c\right) ;{ }^{13} \mathrm{C}$ NMR (150 MHz, pyridine- $\left.d_{5}\right)$ spectroscopic data see Table 2; HR-ESI-MS $m / z 1079.5267\left[\mathrm{M}-\mathrm{H}^{-}\right.$(calcd. for $\mathrm{C}_{51} \mathrm{H}_{83} \mathrm{O}_{24}, 1079.5274$ ).

Allituberoside $\mathrm{M}$ (24): $\mathrm{C}_{45} \mathrm{H}_{74} \mathrm{O}_{19}$; white amorphous powder; $[\alpha]_{\mathrm{D}}^{25}-87.2\left(c 0.039, \mathrm{CH}_{3} \mathrm{OH}\right) ;{ }^{1} \mathrm{H}$ NMR $\left(600 \mathrm{MHz}\right.$, pyridine- $\left.d_{5}\right) \delta 3.93(1 \mathrm{H}, \mathrm{m}, \mathrm{H}-3), 0.77(3 \mathrm{H}, \mathrm{s}, \mathrm{H}-18), 0.89(3 \mathrm{H}, \mathrm{s}, \mathrm{H}-19), 1.08(3 \mathrm{H}, \mathrm{d}$, $J=6.9 \mathrm{~Hz}, \mathrm{H}-21), 4.36\left(1 \mathrm{H}\right.$, overlap, H-27-Ha), $3.92\left(1 \mathrm{H}\right.$, overlap, H-27-Hb), $5.10\left(1 \mathrm{H}, \mathrm{d}, J=7.6 \mathrm{~Hz}, \mathrm{H}-1^{\prime}\right.$ of 3-O-Glc), 6.39 (1H, br s, $\mathrm{H}-1^{\prime \prime}$ of $\left.2^{\prime}-\mathrm{O}-\mathrm{Glc}\right), 4.93\left(1 \mathrm{H}, \mathrm{d}, J=7.8 \mathrm{~Hz}, \mathrm{H}-1^{\prime \prime \prime}\right.$ of $\left.27-\mathrm{O}-\mathrm{Glc}\right) ;{ }^{13} \mathrm{C}$ NMR $\left(150 \mathrm{MHz}\right.$, pyridine- $d_{5}$ ) spectroscopic data see Table 2; HR-ESI-MS m/z $917.4756[\mathrm{M}-\mathrm{H}]^{-}$(calcd. for $\left.\mathrm{C}_{45} \mathrm{H}_{73} \mathrm{O}_{19}, 917.4746\right)$.

Allituberoside $\mathrm{N}(25)$ : $\mathrm{C}_{51} \mathrm{H}_{84} \mathrm{O}_{23}$; white amorphous powder; $[\alpha]_{\mathrm{D}}^{25}-93.8\left(c 0.032, \mathrm{CH}_{3} \mathrm{OH}\right) ;{ }^{1} \mathrm{H}$ NMR $\left(600 \mathrm{MHz}\right.$, pyridine- $\left.d_{5}\right) \delta 3.88(1 \mathrm{H}, \mathrm{m}, \mathrm{H}-3), 0.77(3 \mathrm{H}, \mathrm{s}, \mathrm{H}-18), 0.89(3 \mathrm{H}, \mathrm{s}, \mathrm{H}-19), 1.07(3 \mathrm{H}, \mathrm{d}$, $J=6.3 \mathrm{~Hz}, \mathrm{H}-21), 4.37(1 \mathrm{H}$, overlap, H-27-Ha), $3.92(1 \mathrm{H}, \mathrm{t}, J=8.5 \mathrm{~Hz}, \mathrm{H}-27-\mathrm{Hb}), 5.03(1 \mathrm{H}, \mathrm{d}, J=7.3 \mathrm{~Hz}$, $\mathrm{H}-1^{\prime}$ of 3-O-Glc), $6.40\left(1 \mathrm{H}, \mathrm{br} \mathrm{s}, \mathrm{H}-1^{\prime \prime}\right.$ of $\left.2^{\prime}-\mathrm{O}-\mathrm{Glc}\right), 5.86\left(1 \mathrm{H}, \mathrm{br} \mathrm{s}, \mathrm{H}-1^{\prime \prime \prime}\right.$ of $\left.4^{\prime}-\mathrm{O}-\mathrm{Rha}\right), 4.93(1 \mathrm{H}, \mathrm{d}, J=7.8$ $\mathrm{Hz}, \mathrm{H}-1^{\prime \prime \prime \prime}$ of $\left.27-\mathrm{O}-\mathrm{Glc}\right) ;{ }^{13} \mathrm{C}$ NMR (150 MHz, pyridine- $\left.d_{5}\right)$ spectroscopic data see Table 2; HR-ESI-MS $m / z 1063.5320[\mathrm{M}-\mathrm{H}]^{-}$(calcd. for $\mathrm{C}_{51} \mathrm{H}_{83} \mathrm{O}_{23}, 1063.5325$ ).

Allituberoside $\mathrm{O}(26)$ : $\mathrm{C}_{50} \mathrm{H}_{82} \mathrm{O}_{23}$; white amorphous powder; $[\alpha]_{\mathrm{D}}^{25}-84.6\left(c 0.026, \mathrm{CH}_{3} \mathrm{OH}\right) ;{ }^{1} \mathrm{H}$ NMR (600 MHz, pyridine- $\left.d_{5}\right) \delta 3.88(1 \mathrm{H}, \mathrm{m}, \mathrm{H}-3), 0.77(3 \mathrm{H}, \mathrm{s}, \mathrm{H}-18), 0.89(3 \mathrm{H}, \mathrm{s}, \mathrm{H}-19), 1.07(3 \mathrm{H}, \mathrm{d}$, $J=6.3 \mathrm{~Hz}, \mathrm{H}-21), 4.36(1 \mathrm{H}$, overlap, $\mathrm{H}-27-\mathrm{Ha}), 3.93(1 \mathrm{H}$, overlap, $\mathrm{H}-27-\mathrm{Hb}), 5.03(1 \mathrm{H}, \mathrm{d}, J=7.6 \mathrm{~Hz}$, $\mathrm{H}-1^{\prime}$ of 3-O-Glc), $6.26\left(1 \mathrm{H}, \mathrm{br} \mathrm{s}, \mathrm{H}-1^{\prime \prime}\right.$ of $\left.2^{\prime}-\mathrm{O}-\mathrm{Glc}\right), 5.04\left(1 \mathrm{H}, \mathrm{d}, J=7.6 \mathrm{~Hz}, \mathrm{H}-1^{\prime \prime \prime}\right.$ of $\left.4^{\prime}-\mathrm{O}-\mathrm{Rha}\right), 4.93(1 \mathrm{H}$, $\mathrm{d}, J=7.7 \mathrm{~Hz}, \mathrm{H}-1^{\prime \prime \prime \prime}$ of $\left.27-\mathrm{O}-\mathrm{Glc}\right) ;{ }^{13} \mathrm{C}$ NMR $\left(150 \mathrm{MHz}\right.$, pyridine- $\left.d_{5}\right)$ spectroscopic data see Table 2; HR-ESI-MS $m / z 1049.5180$ [M - H] $]^{-}$(calcd. for $\mathrm{C}_{50} \mathrm{H}_{81} \mathrm{O}_{23}, 1049.5169$ ).

\subsubsection{Acid Hydrolysis and Absolute Configuration Determination}

Compounds 1-10 and 20-26 (each $1.0 \mathrm{mg}$ ) were individually hydrolyzed by heating in $1 \mathrm{~mL}$ of $6 \mathrm{M} \mathrm{TFA}$ at $90^{\circ} \mathrm{C}$ for $2 \mathrm{~h}$. After cooling, the reaction mixture was extracted with $\mathrm{CHCl}_{3}$. Then, each aqueous layer was evaporated to dryness, and the residue was dissolved in $1 \mathrm{~mL}$ of pyridine containing $1 \mathrm{mg}$ of L-cysteine methyl ester hydrochloride and further heated at $60^{\circ} \mathrm{C}$ for $1 \mathrm{~h}$. Following, o-tolyl isothiocyanate $(5 \mu \mathrm{L})$ was added to each mixture, and heated at $60^{\circ} \mathrm{C}$ for $1 \mathrm{~h}$. Standard sugars (each $5 \mathrm{mg}$ ) and L-cysteine methyl ester hydrochloride $(5 \mathrm{mg})$ was dissolved in pyridine $(5 \mathrm{~mL})$ and heated to $60^{\circ} \mathrm{C}$ for $1 \mathrm{~h}$. Then o-tolyl isothiocyanate $(10 \mu \mathrm{L})$ was added to the mixture and refluxed for $1 \mathrm{~h}$. The reaction mixture was analyzed by HPLC. As a result, the D-configurations for glucoses and xylose, L-configrations for rhamnoses in the corresponding compounds were identified by comparing the retention time with the standards. 


\subsection{Bioactivity Assay}

\subsubsection{Preparation of Rat Leydig Cells and Primary Culture}

Leydig cells were isolated from 50-70-day-old Sprague Dawley rats followed the procedure described in the literature with some modifications [28]. In a nutshell, the decapsulated testes were minced into 2-3 mm pieces on the icebox and dispersed in the DME/F-12 medium (Hyclone) for $15 \mathrm{~min}$ at $34^{\circ} \mathrm{C}$ with gentle shaking. The suspension was repeatedly dissociated with a Pasteur pipette to break up large clumps, then dissolved in $0.05 \%$ collagenase I (Invitrogen) dissociation medium. Subsequently, the digestion was stopped by DMEM-F12 culture medium containing 9\% bovine serum albumin, 1\% horse serum, and $0.5 \%$ penicillin-streptomycin mixture (GIBCO), and the solution was filtered through a nylon mesh $(70 \mu \mathrm{m})$. The gradient was centrifuged for $30 \mathrm{~min}$ at $800 \times g$ at $4{ }^{\circ} \mathrm{C}$, and cells localized between Percoll gradient 70 and $58 \%$ were isolated (the second layer). After the repeating wash steps of the medium, the Leydig cells were incubated in the DMEM-F12 culture medium.

The purity of Leydig cells were determined by $3 \beta$-hydroxysteroid dehydrogenase (3 $\beta$-HSD) histochemical staining [29]. Leydig cells were maintained in 24 -well plates at $37{ }^{\circ} \mathrm{C}$ with $5 \% \mathrm{CO}_{2}$. The staining solution contained PBS supplemented with $0.1 \mathrm{mg} / \mathrm{mL}$ nitro-blue tetrazolium (Biosharp), $1.0 \mathrm{mg} / \mathrm{mL}$ nicotinamide adenine dinucleotide (Sigma-Aldrich), $0.1 \mathrm{mg} / \mathrm{mL}$ dehydroepiandrosterone (Sigma-Aldrich, Burlington, MA, USA), and $0.1 \mathrm{mg} / \mathrm{mL}$ niacinamide for $90 \mathrm{~min}$. The positive cells were stained a dark blue.

Animal experiments were approved by the Institutional Animal Care and Use Committee and the local experimental Ethics Committee (Laboratory Animal Certificate no. SYXK2017-0067). Male Sprague-Dawley rats were purchased from the Hubei Provincial Center for Disease Control and Prevention (SCXK 2015-0018; Wuhan, China).

\subsubsection{Cellular Viability and Testosterone Production}

Purified Leydig cells $\left(5 \times 10^{3} / \mathrm{mL}\right)$ were cultured in 96 -well plates at $37^{\circ} \mathrm{C}$ with $5 \% \mathrm{CO}_{2}$ for $48 \mathrm{~h}$. The cells were afterward cultured in serum-free medium containing different doses of compounds, forskolin, HCG (1 IU/mL) for $24 \mathrm{~h}$. Cellular viability was evaluated using the MTT proliferation assay. The MTT (Sigma-Aldrich) solution was maintained for $4 \mathrm{~h}$, then $100 \mu \mathrm{L}$ DMSO was added. Finally, the absorbance was measured at $570 \mathrm{~nm}$ by a microplate reader (Synergy HT). Testosterone secreted into the culture medium was measured using ELISA kits according to the manufacturer's instructions (Nanjing Jiancheng Biological Technology, Nanjing, China).

\section{Conclusions}

This phytochemical work presented a study on ATSs leading to the isolation of 27 steroidal saponins, which facilitates understanding the structural composition of steroidal saponins as the main constituents in ATSs. The subsequent activity assay shows that nearly half of the isolated steroidal glycosides can remarkably promote the testosterone production of rat Leydig cells, proving that the steroidal saponin could be considered as the basis of active material of this traditional herb medicine for playing a role in treating both impotence and nocturnal emissions. The result of this work reveals the active substance basis of ASTs to some extent. Meanwhile, this work clarifies the structure of steroidal saponin in ASTs, establishing a foundation for the quality control research of this traditional medicine.

Supplementary Materials: NMR spectra of compounds 1-27 are available.

Author Contributions: D.-B.Z. performed the whole research study; X.-Y.W. planned, designed and organized the whole research study. All authors have read and agreed to the published version of the manuscript.

Funding: This research received no external funding.

Conflicts of Interest: There are no conflicts of interests of all authors. 


\section{References}

1. Williams, J.R.; Gong, H. Biological activities and syntheses of steroidal saponins: the shark-repelling pavoninins. Lipids 2007, 42, 77-86. [CrossRef]

2. Qin, Y.; Wu, X.; Huang, W.; Gong, G.; Li, D.; He, Y.; Zhao, Y. Acute toxicity and sub-chronic toxicity of steroidal saponins from Dioscorea zingiberensis C.H. Wright in rodents. J. Ethnopharmacol. 2009, 126, 543-550. [CrossRef]

3. Chen, M.H.; Chen, X.J.; Wang, M.; Lin, L.G.; Wang, Y.T. Ophiopogon japonicus-A phytochemical, ethnomedicinal and pharmacological review. J. Ethnopharmacol. 2016, 181, 193-213. [CrossRef]

4. Wang, Y.H.; Niu, H.M.; Zhang, Z.Y.; Hu, X.Y.; Li, H. Medicinal values and their chemical bases of Paris. Zhongguo Zhongyao Zazhi 2015, 40, 833-839. (In Chinese) [PubMed]

5. Wang, Y.; Xu, L.; Lou, L.L.; Song, S.J.; Yao, G.D.; Ge, M.Y.; Hayashi, T.; Tashiro, S.I.; Onodera, S.; Ikejima, T. Timosaponin AIII induces apoptosis and autophagy in human melanoma A375-S2 cells. Arch. Pharm. Res. 2016, 40, 69-78. [CrossRef] [PubMed]

6. Sobolewska, D.; Michalska, K.; Podolak, I.; Grabowska, K. Steroidal saponins from the genus Allium. Phytochem. Rev. 2016, 15, 1-35. [CrossRef] [PubMed]

7. Hu, G.H.; Lu, Y.H.; Mao, R.G.; Wei, D.Z.; Ma, Z.Z.; Zhang, H. Aphrodisiac properties of Allium tuberosum seeds extract. J. Ethnopharmacol. 2009, 122, 579-582.

8. Kim, S.Y.; Park, K.W.; Kim, J.Y.; Jeong, I.Y.; Byun, M.W.; Park, J.E.; Yee, S.T.; Kim, K.H.; Rhim, J.S.; Yamada, K.; et al. Thiosulfinates from Allium tuberosum L. induce apoptosis via caspase-dependent and -independent pathways in PC-3 human prostate cancer cells. Bioorg. Med. Chem. Lett. 2008, 18, 199-204. [CrossRef]

9. Park, K.W.; Kim, S.Y.; Jeong, I.Y.; Byun, M.W.; Park, K.H.; Yamada, K.; Seo, K.I. Cytotoxic and antitumor activities of thiosulfinates from Allium tuberosum L. J. Agric. Food Chem. 2007, 55, 7957-7961. [CrossRef]

10. Lee, J.H.; Yang, H.S.; Park, K.W.; Kim, J.Y.; Lee, M.K.; Jeong, I.Y.; Shim, K.H.; Kim, Y.S.; Yamada, K.; Seo, K.I. Mechanisms of thiosulfinates from Allium tuberosum L.-induced apoptosis in HT-29 human colon cancer cells. Toxicol. Lett. 2009, 188, 142-147. [CrossRef]

11. Sang, S.M.; Lao, A.N.; Wang, H.C.; Chen, Z.L. Furostanol saponins from Allium tuberosum. Phytochemistry 1999, 52, 1611-1615. [CrossRef]

12. Sang, S.M.; Lao, A.N.; Wang, H.C.; Chen, Z.L. Two new spirostanol saponins from Allium tuberosum. J. Nat. Prod. 1999, 62, 1028-1029. [CrossRef] [PubMed]

13. Sang, S.M.; Zou, M.L.; Xia, Z.H.; Lao, A.N.; Chen, Z.L.; Ho, C.T. New spirostanol saponins from Chinese chives (Allium tuberosum). J. Agric. Food Chem. 2001, 49, 4780-4783. [CrossRef] [PubMed]

14. Sang, S.M.; Mao, S.L.; Lao, A.N.; Chen, Z.L.; Ho, C.T. Four new steroidal saponins from the seeds of Allium tuberosum. J. Agric. Food Chem. 2001, 49, 1475-1478. [CrossRef]

15. Zou, Z.M.; Yu, D.Q.; Cong, P.Z. A steroidal saponin from the seeds of Allium tuberosum. Phytochemistry 2001, 57, 1219-1222. [CrossRef]

16. Fang, Y.S.; Cai, L.; Li, Y.; Wang, J.P.; Xiao, H.; Ding, Z.T. Spirostanol steroids from the roots of Allium tuberosum. Steroids 2015, 100, 1-4. [CrossRef]

17. Ikeda, T.; Tsumagari, H.; Nohara, T. Steroidal oligoglycosides from the seeds of Allium tuberosum. Chem. Pharm. Bull. 2000, 48, 362-365. [CrossRef]

18. Gupta, R.K.; Jain, D.C.; Thakur, R.S. Two furostanol saponins from Trigonella foenum-graecum. Phytochemistry 1986, 25, 2205-2207. [CrossRef]

19. Murakami, T.; Kishi, A.; Matsuda, H.; Yoshikawa, M. Medicinal foodstuffs. XVII. Fenugreek seed. (3): Structures of new furostanol-type steroid saponins, trigoneosides $\mathrm{Xa}, \mathrm{Xb}, \mathrm{XIb}, \mathrm{XIIa}, \mathrm{XIIb}$, and XIIIa, from the seeds of Egyptian trigonella foenum-graecum L. Chem. Pharm. Bull. 2000, 48, 994-1000. [CrossRef]

20. Shvets, S.A.; Gutsu, O.N.; Kintia, P.K. Steroidal glycosides from Nicotiana tabacum L. seeds and their biological activity. Adv. Exp. Med. Biol. 1996, 405, 247-257.

21. Zuo, Y.M.; Xu, Y.L.; Zhang, Z.L.; Liu, D.H.; Cai, M.T. Chemical components in roots and rhizome of Trillium tschonoskii (V). Shizhen Guoyi Guoyao 2016, 27, 260-263. (In Chinese)

22. Hayes, P.Y.; Jahidin, A.H.; Lehmann, R.; Penman, K.; Kitching, W.; De Voss, J.J. Structural revision of shatavarins I and IV, the major components from the roots of Asparagus racemosus. Tetrahedron Lett. 2006, 47, 6965-6969. [CrossRef] 
23. Hu, K.; Dong, A.J.; Yao, X.S.; Kobayashi, H.; Iwasaki, S. Antineoplastic agents. Part 2. Four furostanol glycosides from rhizomes of Dioscorea collettii var. hypoglauca. Planta Med. 1997, 63, 161-165. [CrossRef] [PubMed]

24. Huang, H.L.; Liu, R.H.; Shao, F. Structural determination of two new steroidal saponins from Smilax china. Magn. Reson. Chem. 2009, 47, 741-745. [CrossRef] [PubMed]

25. Jian, R.; Zeng, K.W.; Li, J.; Li, N.; Jiang, Y.; Tu, P.F. Anti-neuroinflammatory constituents from Asparagus cochinchinensis. Fitoterapia 2013, 84, 80-84. [CrossRef] [PubMed]

26. Agrawal, P.K. Dependence of ${ }^{1} \mathrm{H}-\mathrm{NMR}$ chemical shifts of geminal protons of glycosyloxy methylene $\left(\mathrm{H}_{2}-26\right)$ on the orientation of the 27-methyl group of furostane-type steroidal saponins. Magn. Reson. Chem. 2004, 42, 990-993. [CrossRef] [PubMed]

27. Ono, M.; Takamura, C.; Sugita, F.; Masuoka, C.; Yoshimitsu, H.; Ikeda, T.; Nohara, T. Two new steroid glycosides and a new sesquiterpenoid glycoside from the underground parts of Trillium kamtschaticum. Chem. Pharm. Bull. 2007, 55, 551-556. [CrossRef] [PubMed]

28. Sharma, R.S.; Pal, P.C.; Rajalakshmi, M. Isolation and culture of Leydig cells from adult rats. Indian J. Clin. Biochem. 2006, 21, 27-33. [CrossRef]

29. Wisniewski, J.R.; Zougman, A.; Nagaraj, N.; Mann, M. Universal sample preparation method for proteome analysis. Nat. Methods 2009, 6, 359-362. [CrossRef]

Sample Availability: Not available.

Publisher's Note: MDPI stays neutral with regard to jurisdictional claims in published maps and institutional affiliations.

(C) 2020 by the authors. Licensee MDPI, Basel, Switzerland. This article is an open access article distributed under the terms and conditions of the Creative Commons Attribution (CC BY) license (http://creativecommons.org/licenses/by/4.0/). 